\title{
THE RIPHEAN MAGMATISM PRECEDING THE OPENING OF URALIAN PALEOOCEAN: GEOCHEMISTRY, ISOTOPES, AGE, AND GEODYNAMIC IMPLICATIONS
}

\author{
V. V. Kholodnov ${ }^{1}$, G. Yu. Shardakova1, 2, G. B. Fershtater ${ }^{1}$, E. S. Shagalov1, 2 \\ ${ }^{1}$ A.N. Zavaritsky Institute of Geology and Geochemistry, Ural Branch of RAS, Yekaterinburg, Russia \\ 2 Ural State Mining University, Yekaterinburg, Russia
}

\begin{abstract}
The rocks from different stages of the geodynamic evolution have been preserved in the Urals. In its geologic history, the least studied is the transition period between continental rifting and the beginning of oceanic spreading. This article presents the geochemical data on the Sr-, Nd-isotopes, zircon U-Pb (SHRIMP) ages for the MesoNeoproterozoic igneous rocks and associated ores from the Bashkir meganticlinorium (BMA) on the Urals western slope. A Large Igneous Province (LIP) formed there as a result of mantle plume activity during the Middle Riphean (1380-1350 Ma). Later on (1200-1100 Ma), short-term rifting took place, as evidenced by the Nazyam graben, which was followed by the complete break-up of the continental crust. For magmatic rocks in the age range of 1750-1200 $\mathrm{Ma}$, the evolition of chemical composition OIB-type $\rightarrow$ E-MORB $\rightarrow \mathrm{N}$-MORB is observed. The $\varepsilon N \mathrm{~d}_{(\mathrm{t})}$ values for the igneous rocks and the associated BMA ores vary from negative $(-6)$ to positive ones $(+5)$, and thus give evidence of the lithosphere mantle depletion with time. These facts and the Sr-isotope ratios for the magmatic rocks from the subsequent evolution stages confirm that the oceanic basin to the east of the East European platform started to open at the end of the Middle Riphean. For the Vendian-Cambrian, some traces of orogenes (Timanian stage) are observed. The development of the Uralian Paleozoic ocean started in the Ordovican and continued up to the Late CarboniferousPermian.
\end{abstract}

Key words: geochemistry; Sr- and Nd-isotopes; dike swarms; Riphean; intra-plate rifting; Urals

\section{RESEARCH ARTICLE}

Handling Editor: E.V. Sklyarov
Received: February 8, 2018

Revised: May 10, 2018

Accepted: May 23, 2018

For citation: Kholodnov V.V., Shardakova G.Yu., Fershtater G.B., Shagalov E.S., 2018. The Riphean magmatism preceding the opening of Uralian paleoocean: geochemistry, isotopes, age, and geodynamic implications. Geodynamics \& Tectonophysics 9 (2), 365-389. doi:10.5800/GT2018-9-2-0351. 


\title{
РИФЕЙСКИЙ МАГМАТИЗМ, ПРЕДШЕСТВУЮЩИЙ РАСКРЫТИЮ УРАЛЬСКОГО ПАЛЕООКЕАНА: ГЕОХИМИЯ, ИЗОТОПИЯ, ВОЗРАСТ, ГЕОДИНАМИЧЕСКИЕ СЛЕДСТВИЯ
}

\author{
В. В. Холодновㅁ, Г. Ю. Шардакова', 2, Г. Б. Ферштатер¹, Е. С. Шагалов ${ }^{1,2}$ \\ ${ }^{1}$ Институт геологии и геохимии им. акад. А.Н. Заварицкого УрО РАН, Екатеринбург, Россия \\ 2 Уральский государственный горный университет, Екатеринбург, Россия
}

\begin{abstract}
Аннотация: Урал - одна из немногих структур, в которой сохранились породы всех стадий геодинамической эволюции. Наименее изученным в его геологической истории является период, переходный от континентального рифтинга к океаническому спредингу. В статье представлены новые данные по геохимии, изотопии $\mathrm{Sr}$ и Nd, U-Pb (SHRIMP) возрасту цирконов магматических пород и связанных с ними руд Башкирского мегантиклинория (западный склон Южного Урала), имеющих мезонеопротерозойский возраст. В среднем рифее (1380-1350 млн лет) здесь была сформирована крупная изверженная провинция (LIP) как возможный результат активности мантийного плюма. Затем (около 1100 млн лет) имел место полный разрыв континентальной коры, и краткое время существовала рифтовая структура (Назямский грабен). Для магматических пород с возрастом 1750-1100 млн лет фиксируется геохимическая эволюция составов: OIB $\rightarrow \mathrm{E}-\mathrm{MORB} \rightarrow$ N-MORB. При этом $\varepsilon N d$ изменяется от отрицательных (-6) до положительных значений (+5), указывая на обеднение литосферной мантии со временем. Эти факты, наряду с поведением изотопов Sr для пород всех последующих стадий эволюции Урала, указывают на то, что океаническое пространство к востоку от Восточно-Европейской платформы открылось в конце среднего рифея. В венде - кембрии присутствуют признаки орогенных событий (Тиманский этап). С ордовика началось развитие Уральского палеозойского океана, существовавшего до верхнего карбона - ранней перми.
\end{abstract}

Ключевые слова: геохимия; изотопия $\mathrm{Sr}$ и $\mathrm{Nd}$; дайковые рои; рифей; внутриплитный рифтинг; Урал

\section{INTRODUCTION}

The Uralian Mobile Belt is one of a few geologic structures on the Earth where the rocks from the different stages of the geodynamic evolution have been preserved. The Urals is composed of the rocks representing all the geodynamic settings, from continental rifting (the edge of the East European Platform, EEP) and opening of the oceanic basin in the Late MesoProterozoic (the area to the east of EEP) to the Carboniferous-Permian collision.

The time of the oceanic basin opening at the EEP edge and the factors initiating that process have been discussed in many papers. The literature overview shows that intraplate rifting, subduction, accretion and collision occurred at the EEP eastern margin in the Precambrian [Maslov et al., 1997; Kuznetsov et al., 2007; Nosova et al., 2009; Samygin et al., 2010; Puchkov, 2013; Ivanov et al., 2014], and different parts of that extended zone did not develop quite synchronously.

The main structure comprising various magmatic formations under study is the Bashkir Meganticlinorium (BMA) (Figures 1, 2, and 3). It is located at the borderline between the Urals and EEP. In our study, we analyzed the composition, age, isotope characteristics and geodynamic settings of the BMA Pre-Cambrian igneous rocks, and tried to determine the nature of magmatism in the early evolutionary stages of the structure, the time of origin and duration of the paleoocean.

For describing the age of the Uralian formations, we use the terms "the Riphean" and "the Vendian". The Lower and Middle Riphean correspond to MesoProterozoic; the Late and Uppermost Riphean (760$600 \mathrm{Ma}$ [ [Puchkov, 2010; Krasnobaev et al., 2012] refer to the Early and Middle Neoproterozoic; and the Vendian corresponds to the Late Neoproterozoic.

\section{BRIEF GEOLOGICAL DESCRIPTION OF THE BASHKIR MEGANTICLINORIUM}

The Bashkir Meganticlinorium (BMA) is located on the western slope of the Urals. It is a part of the Central Uralian megazone (Fig. 1). In the west, it borders the West Uralian megazone and the Preuralian Foredeep at the EEP eastern edge. In the east and southeast, it adjoins (from the north to the south) the Ufaley block, the Magnitogorsk megazone, and the Uraltau anticline structure [Puchkov, 2010]. The western and eastern 


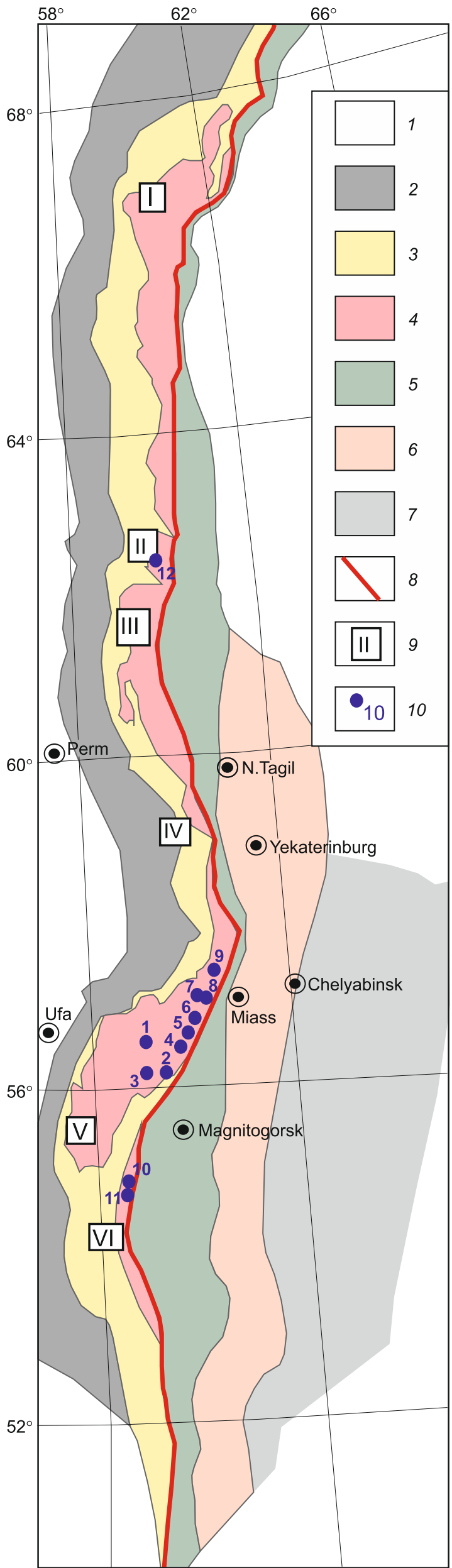

Fig. 1. Tectonic scheme of the Urals, after [Puchkov, 2010].

1 - East European and West Siberian platforms; 2 - Preuralian foredeep; 3 - West Uralian zone; 4 - Central Uralian zone; 5 Tagil (northern part) - Magnitogorsk (southern part) zone; 6 East Uralian zone; 7 - Transuralian zone; 8 - Main Uralian Fault; 9 - anticline structures: I - Lyapin, II - Isherim, III - KvarkushKamennogorsk, IV - Ufaley, V - Bashkir, VI - Uraltau; 10 (blue digits, 1 to 12) - objects described in the text: 1 - Berdyaush pluton, 2 - Akhmerovo massif, 3 - Sibirka deposit, 4-7 - main members of the Kusa-Kopan group (4 - Ryabinovka and 6 - Gubenka granite massifs, 5 - Kopan and 7 - Kusa gabbro massifs), 8 - amphibolites (metabasalts) of the Nazyan sequence, 9 - dolerite dikes in the Alexandrovsk-Akhtensk block, 10 - Barangul gabbrogranite and 11 - Mazara granite massifs, 12 - dolerile sill intruded quartzite sandstones of the Isherim Formation (see in text). More massifs are shown in Figs. 2 and 3.

Рис. 1. Тектоническая схема Урала, по [Puchkov, 2010].

1 - Восточно-Европейская и Западно-Сибирская платформы; 2 - Предуральский краевой прогиб; 3 - Западно-Уральская зона; 4 - Центрально-Уральская зона; 5 - Тагило(северная часть) - Магнитогорская (южная часть) зона; 6 - ВосточноУральская зона; 7 - Зауральская зона; 8 - Главный Уральский разлом; 9 - антиклинории: I - Ляпинский, II - Ишеримский, III - Кваркушско-Каменногорский, IV - Уфалейский, V Башкирский, VI - Уралтаусский; 10 - объекты, упоминаемые в тесте (синие цифры от 1 до 12): 1 - Бердяушский плутон, 2 - Ахмеровский массив, 3 - месторождение Сибирка, 4-7 члены Кусинско-Копаской группы интрузий (4 - Рябиновский и 6 - Губенский гранитные массивы, 5 - Копанский и 7 - Кусинский габбровые массивы), 8 - амфиболиты (метабазальты) назямской толщи, 9 - долеритовые дайки в Александровско-Ахтенском блоке, 10 - Барангуловский габброгранитный и 11 - Мазаринский гранитный массивы, 12 долеритовый силл (прорывает кварцитовидные песчаники ишеримской свиты (см. текст). Остальные массивы показаны на рис. 2 и 3. 


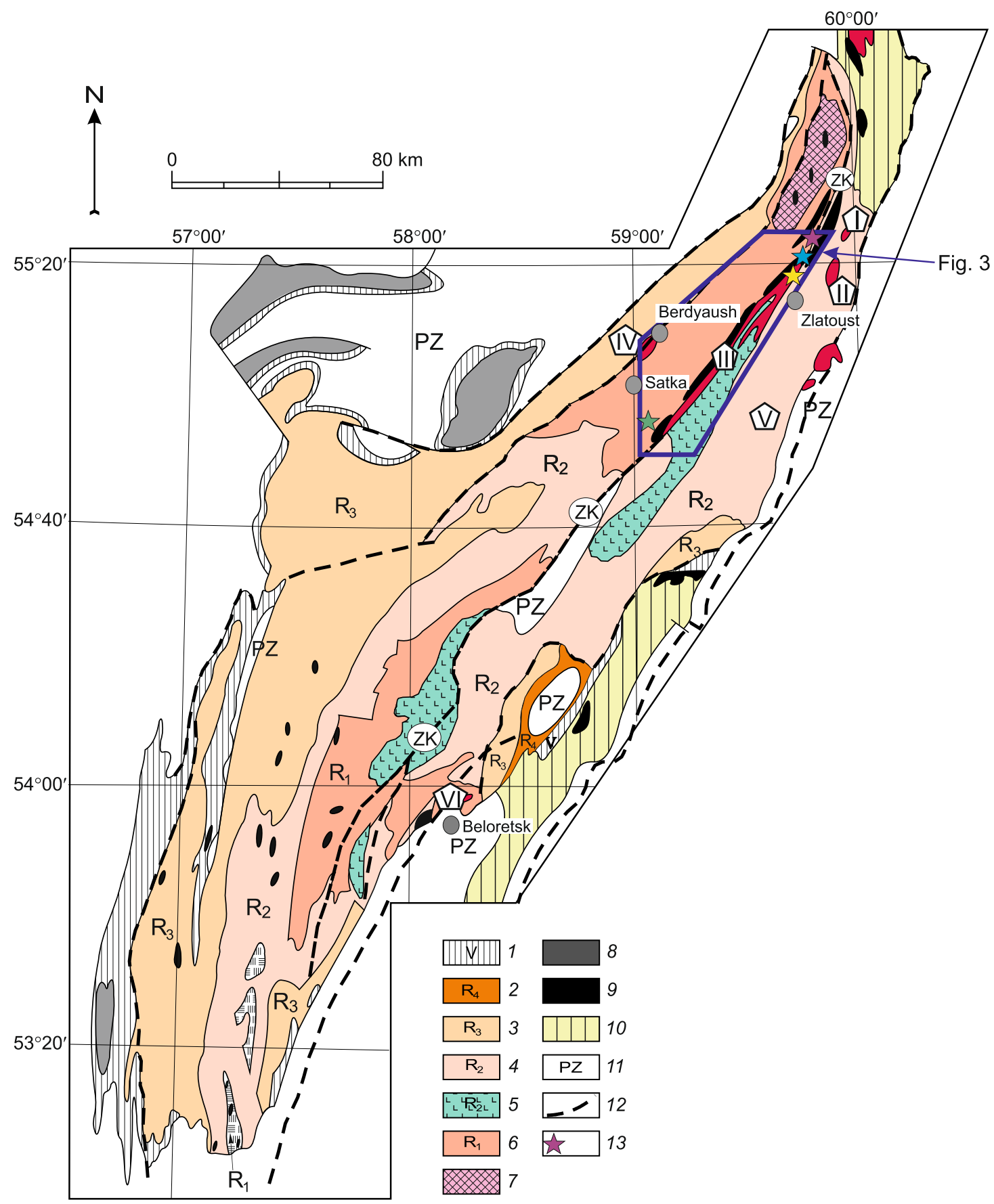

Fig. 2. Schematic geological map of the Bashkir Meganticlinorium (BMA), modified after [Sobolev, 1977; Ernst et al., 2006].

1-6 - Precambrian sedimentary sequences: 1 - Vendian, 2 - Uppermost Riphean, 3 - Late Riphean, 4-5 - Middle Riphean formations: 4 sedimentary sequences (united) and, separately, 5 - Mashak Formation; 6 - Early Riphean formations; 7 - Taratash metamorphic complex; 8 - granitoids (I - Yurma complex, II - Kialim massif, III - Ryabinovka and Gubenka massifs, IV - Semibratka complex, V - Berdyaush pluton, VI - Akhmerovo massif); 9 - diabase, gabbro; 10 - Paleozoic sediments; 11 - geological boundaries; 12 - faults; 13 (asterisks) - offscale objects: green - Sibirka deposit; yellow - Nazyam metabasalts; light blue - borehole no. 2; violet - dike near the Akhtensk metamorphic block. ZK - Zyuratkul-Karatash fault.

Рис. 2. Схематическая геологическая карта Башкирского мегантиклинория, по [Sobolev, 1977; Ernst et al., 2006] с дополнениями.

1-6 - докембрийские осадочные формации: 1 - венд, 2 - терминальный рифей, 3 - верхний рифей, 4-5 - свиты среднего рифея: 4 - осадочные формации (объединенные) и отдельно, 5 - машакская свита; 6 - свиты нижнего рифея; 7 - Тараташский метаморфический комплекс; 8 - гранитоиды (I - юрминский комплекс, II - Киалимский массив, III - Рябиновский и Губенский массивы, IV - семибратский комплекс, V - Бердяушский плутон, VI - Ахмеровский массив); 9 - долериты, габбро; 10 - палеозойские осадочные формации; 11 - геологические границы; 12 - разломы; 13 (звездочки) - внемасштабные объекты: зеленый - месторождение Сибирка; желтый - назямские амфиболиты (метабазальты); голубой - скв. 2; фиолетовый - дайки в контурах Ахтенского метаморфического блока. ZK - Зюраткульско-Караташский разлом. 


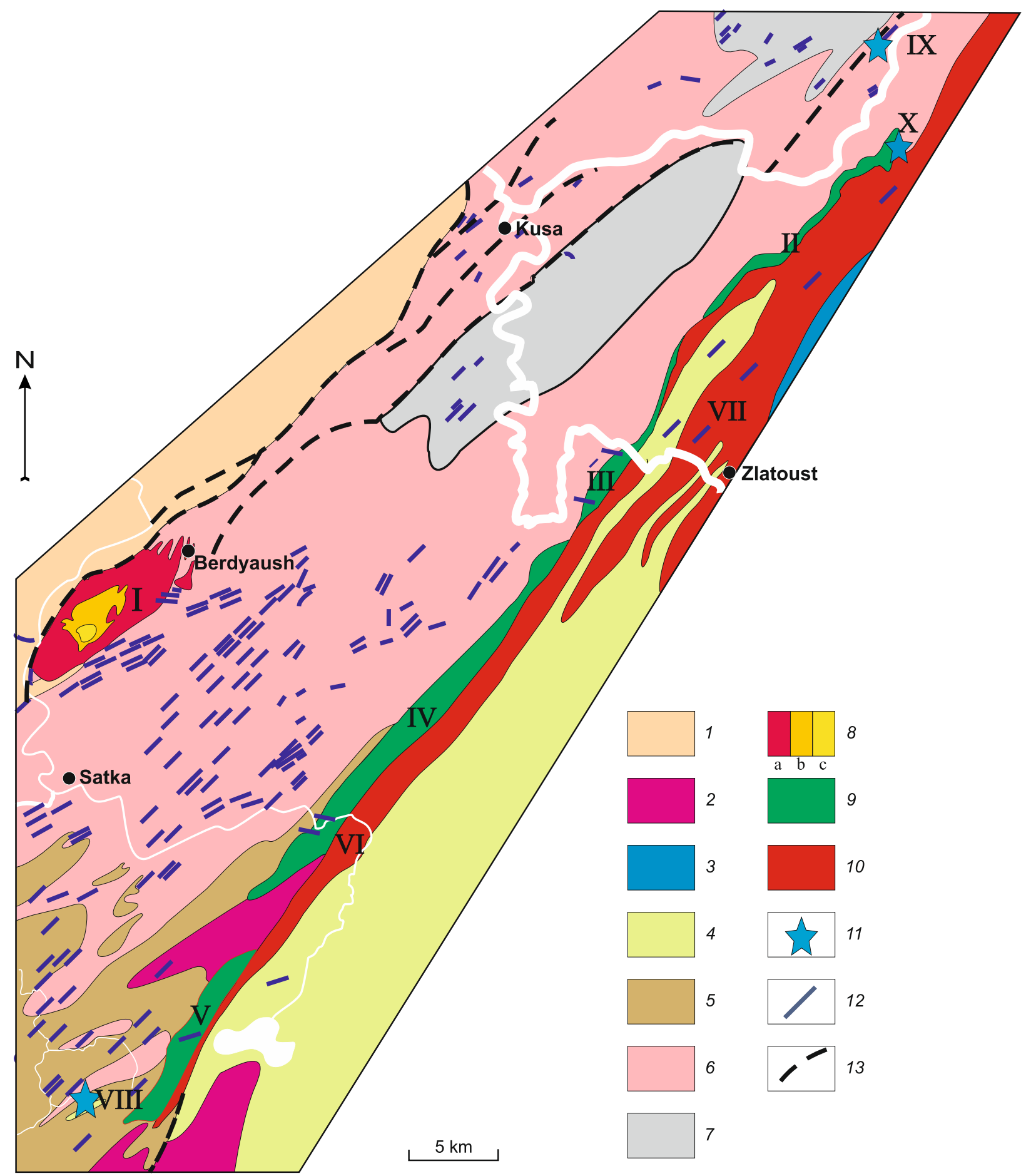

Fig. 3. Geological scheme (1:200000) of the area of the Kusa-Kopan intrusion and its frame [Garan et al., 1964].

1-7 - Riphean formations: 1 - Zilmerdak and Katav, 2 - Zigalga, 3 - Nazyam, 4 - Mashak and Kuvash (analogues), 5 - Bakal, 6 - Satka, 7 Ai. Intrusive massifs: 8 - Berdyaush pluton: $\mathrm{a}$ - nepheline syenites, b - syenites, $\mathrm{c}$ - rapakivi granite (with small gabbro bodies); 9 - massifs of the Kusa-Kopan complex: gabbro: II - Kusa, III - Medvedevka, IV - Kopan, V - Matkal, 10 - granites: VI - Ryabinovka, VII - Gubenka; 11 - deposits: VIII - Sibirka, IX - Akhtensk (metamorphic rocks with dikes, see text); 12 - picrites and dolerites dikes; 13 - faults.

Рис. 3. Геологическая схема (1:200000) района Кусинско-Копанской интрузии и ее обрамления [Garan et al., 1964].

1-7 - рифейские формации (свиты): 1 - зильмердакская и катавская, 2 - зигальгинская, 3 - назямская толща, 4 - машакская и кувашская (аналоги), 5 - бакальская, 6 - саткинская, 7 - айская. Интрузивные массивы: 8 - Бердяушский плутон: а - нефелиновые сиениты, b - сиениты, с - граниты рапакиви (с мелкими телами габброидов); 9 - массивы Кусинско-Копанского комплекса: габброидные: II - Кусинский, III - Медведевский, IV - Копанский, V - Маткальский; 10 - гранитные: VI - Рябиновский, VII - Губенский; 11 - месторождения: VIII - Сибирка, IX - Ахтенское (метаморфические породы и дайки, см. текст); 12 - дайки долеритов и пикритов; 13 - разломы. 
zones of BMA differ in the stage of metamorphic alteration of rocks. The Zuratkul-Karatash (ZK) fault is the borderline between these zones.

The BMA sedimentary units form three structural levels: the Archaean-Lower Proterozoic, Riphean, and Vendian-Paleozoic, separated by stratigraphic and angular unconformities. The most ancient (orthomagmatic?) rocks are observed in the Taratash and Alexandrovka metamorphic complexes, considered to be the fragments of the EEP crystalline basement (2915$1800 \mathrm{Ma}$ ) [Puchkov et al., 2013]. The zircon ages of metabasalts in the above-mentioned complexes are $2608 \pm 25$ and 2054 \pm 8.5 Ma [Ronkin et al., 2007; Puchkov et al., 2013; Tevelev et al., 2014a, 2017]. The ages of detritic zircons (inherited from Taratash rocks) from sandstones of the Zigalga formation $\left(\mathrm{R}_{2}\right)$ range from 2100 to $1800 \mathrm{Ma}$ and may suggest the time of an ancient collision [Kuznetsov et al., 2017].

The 15-17 km thick Riphean deposits lie with an angular unconformity on the Lower Precambrian rocks. Sedimentary series (groups) are as follows: (1) Burzyanian, Lower Riphean (Ai, Satka, and Bakal Formations (Fm.); (2) Yurmatian, Middle Riphean (Mashak, Zigalga, Zigazino-Komara, Avzyan Fm.); (3) Karatavian, Late Riphean (Zilmerdak, Katav, Inser, Minyar, Uk Fm.); (4) Arshinian, Uppermost Riphean [Krasnobaev et al., 2012]. These groups represent the transgressive cycles of sedimentation, separated from each other by stratigraphic gaps. The basal parts of the cycles are coarse-grained; volcanics are present at the base of the Burzyanian and Yurmatian (see below); the upper parts of the cycles are composed of clay-carbonate rocks [Stratotype of the Riphean..., 1983; Parnachev, 1981; Maslov et al., 1997; Maslov, 2004; Puchkov, 2010].

The Vendian deposits lie on the Riphean ones with an unconformity. The Vendian deposits are represented by the Asha group (terrigenous rocks), subdivided into seven formations. The interval of their generation is 618-547.6 Ma [Grazhdankin et al., 2011; Levashova et al., 2013].

The Paleozoic deposits are developed in the sinclines (Yuryuzan, and Tyrlyan) in the eastern BMA. On the BMA western slope, the Paleozoic deposits overlie the Vendian sequences with a parallel unconformity. The Ordovician sandstones and the Silurian shales lie unconformably on the deformed Middle-Late Riphean rocks.

According to the data on the regional stratigraphy, lithology and tectonics, the EEP eastern margin developed as a passive margin during the Riphean - Early Vendian, with several episodes of rifting and subsequent formation of well-known supra-rift depressions. The types of sedimentary basins varied with time. The intracratonic basin developed in the Lower and Middle Riphean and was transformed in the Late Riphean into a pericratonic basin, from the western slope of the Urals through the Timan ridge to the Kola Peninsula [Maslov et al., 1997]. In the Late Vendian, there was a deep foreland basin filled with molassa [Puchkov, 2013] from the beginning of the Timan activity in the east. According to the recent datings of detritic zircons [Kuznetsov et al., 2014], the detritic material began to transport from the Pre-Uralian-Timan orogen to the Mezen' sedimentary basin only in the Early Cambrian. It means the start of the Timan orogenic process. Before that event, the Timan edge of the Baltica continent developed as a passive margin.

In the Early Paleozoic, there was a shelf basin in the east of EEP. The positions of the sedimentary sequences (from the Ordovician to Devonian) in the geological section suggest at the basin's extension in the western direction [Puchkov, 2010; etc.].

The BMA magmatic formations are concentrated in its eastern part. The Riphean stage includes the Early Riphean subalkaline basalts of the Ai Fm. (western BMA, 1752 $\pm 18 \mathrm{Ma}$ ] [Krasnobaev et al., 2013; Tevelev et al., 2014], and the Middle Riphean subalkaline rhyolitebasalts of the Mashak Fm (east of BMA, 1380-1350 Ma) [Parnachev, 1981; Puchkov et al., 2013]. The swarms of basic dikes in different parts of BMA, the Berdyaush and Akhmerovo massifs, the gabbro-granitoid intrusions of the Kusa group, and the Sibirka trachybasalts are comagmatic with basalts of the Mashak Fm. All these objects are considered below. During the Uppermost Riphean (728-700 Ma), the metabasalts of the Arsha group (Igonino suite), Barangulovo and Mazara gabbro-granite massifs were formed [Kuznetsov, 2009; Krasnobaev et al., 2015]. The petrogeochemical features of the Riphean magmatic rocks show their generation in the continental rifting setting at the eastern margin of EEP.

The age of zircons from the ash layer (molassa, Late Vendian) is $548.2 \pm 7.6 \mathrm{Ma}$ [Grazhdankin et al., 2011].The age of granite gneisses from the Jurma complex in the east of BMA is 540-510 Ma [Shardakova, 2016]. In petrogeochemistry, volcanic rocks correspond to riftogenic series, granitoids to A-type of granites, which have characteristics of both riftogenic and suprasubduction series. In the eastern BMA, there are two small granite massifs of the Paleozoic age - Semibratka and Kialim (314-300 Ma) [Shardakova, 2016]. Their datings and petrogeochemistry are close to typical early orogenic series located to the east of the Main Uralian Fault zone and associated with the development of collision in the Urals.

Thus, the BMA geologic structure reflects the features of various geodynamic settings. The Pre-Uralian structural level (Late Precambrian, according to [Puchkov, 2013]) reflects the evolution of the continental margin with the episodes of rifting, and the Uralian structural level (Paleozoic) demonstrates subsequent 
processes, from the further opening of the ocean to its closure and the generation of the collision orogen.

Below we describe the types of magmatic associations which characterize the geodynamic settings of the early stages of the Riphean-Vendian ocean opening.

\section{RESEARCH METHODS}

The analyses for major and trace elements were performed at Center Geoanalitik and the Laboratory of Physical and Chemical Methods of Research at the Institute of Geology and Geochemistry, Uralian Branch of RAS (Ekaterinburg).

The concentrations of major elements were determined by X-ray spectroscopy XRF (VRA-30) (analysts N.P. Berseneva and G.S. Neupokoeva). The $\mathrm{Fe}_{2} \mathrm{O}_{3}$ and $\mathrm{Na}_{2} \mathrm{O}$ contents and loss-on-ignition values were determined by the wet chemistry technique. Total iron is presented as $\mathrm{FeO}$.

The analytical measurements of rare and rare-earth elements were conducted using an ElmerELAN 9000 ICP-MS spectrometer (analyst D.V. Kiseleva). The analytical errors were $2 \%$ for concentrations over $100 \mathrm{ppm}$ and $5 \%$ for concentrations below $10 \mathrm{ppm}$. The Sm and Nd concentrations and isotope compositions were analyzed by isotopic dilution mass spectrometry. The analytical errors of determination of ${ }^{147} \mathrm{Sm} /{ }^{144} \mathrm{Nd}$ and ${ }^{143} \mathrm{Nd} /{ }^{144} \mathrm{Nd}$ ratios were $0.2 \%( \pm 2 \sigma)$ and $0.003 \%( \pm 2 \sigma)$, respectively. The certified international standards (La Jolla and BCR-2) were used to evaluate the quality of the data obtained. The Sm-Nd isotope data were processed using the Isoplot/Ex ver. 2.49 software to reveal the $\mathrm{Sm}-\mathrm{Nd}$ isotopic evolution [Ludwig, 2001].

Single zircon grains were analyzed at the Center of Isotopic Researches, A.P. Karpinsky Russian Geological Research Institute (VSEGEI, St-Petersburg) by analysts D.V. Matukov and E.V. Lepekhina. The U-Pb analysis of zircon grains was performed on a SHRIMP-II ion microprobe following the standard procedure [Williams, 1998].

\section{RESULTS. CHEMICAL COMPOSITION AND GEOCHRONOLOGY OF THE RIPHEAN IGNEOUS COMPLEXES OF BMA}

The data on the geology, chemical compositions and ages of most of the Precambrian igneous complexes of the BMA are shown in Figures 4 and 5, and Tables 1, 2, and 3. First, we briefly describe the well-known objects (Berdyaush and Akhmerovo massifs, basalts of the Ai Fm.) to show a full picture of magmatic events. Then the results of our investigation of the rocks of the KusaKopan group of intrusions, the Sibirka deposit, the
Nazyam sequence, and the sill-and-dike swarms are presented in detail.

Early Riphean stage. Basalts of the Ai formation are the most ancient igneous rocks of this stage in the study area; $1752 \pm 18$ Ma [Krasnobaev et al., 2013]. Their chemical composition indicate [Parnachev, 1981; Ernst et al., 2006; etc.] relatively high alkalinity of rocks, which are characterized by $\mathrm{K}_{2} \mathrm{O} 3-6 \%$, $\mathrm{TiO}_{2}$ $2-3 \%, \mathrm{P}_{2} \mathrm{O}_{5}$ up to $0.70 \%$ contents, as well as a sharp prevalence of light rare-earth elements (LREE) over heavy rare-earth elements (HREE) (see Table 1). According to the contents and ratios of trace elements, the trachybasalts of the Ai Fm. are close to ocean island basalts (OIB-type).

Middle Riphean stage. The Berdyaush granite massif. The Berdyaush massif is located near the eponymous railway station, to the east of the Kusa-Kopan cluster of intrusions. From the east, the massif is bounded by a fault zone; in the west, it intruded the Lower Riphean metasediments of the Satka Fm. The core of the Berdyaush massif is represented by syenodiorites and syenites containing gabbro xenoliths, as well as by the bodies of nepheline syenite; a peripheral zone of the massif is composed of granosyenites and rapakivi granites. The latter are related to A-granites formed during extension. The Berdyaush pluton is composed of typical intraplate rift-related series of the BMA. It is described in detail by many authors [Popov et al., 2002; Krasnobaev et al., 2011; Puchkov, 2013; Shardakova, 2016; Ronkin et al., 2016; etc.].

The gabbroids of the Berdyaush massif are very specific. According to the contents of HFSE (Nb, Ta, Y, $\mathrm{Hf}$, and $\mathrm{Zr}$ ), $\mathrm{La} / \mathrm{Yb}, \mathrm{Nb} / \mathrm{Zr}$, and $\mathrm{Y} / \mathrm{Zr}$ ratios (Figs 5 , and 6), they are similar to subalkaline dikes cutting the Lower Proterozoic rocks of the AlexandrovskAkhtensk metamorphic complex (see below). Apparently, such rocks are related to a more enriched mantle source.

The following ages were obtained for different rocks of the Berdyaush pluton: 1388 Ma (gabbroids), 1372 Ma (quartz syenite porphyry), 1388-1354 Ma (rapakivi granites), and 1373-1368 Ma (nepheline syenite) [Krasnobaev et al., 2011; Ronkin et al., 2006; etc.]. These datings lie in the age range of formation of the Kusa-Kopan gabbro-granite complex and determine the lower age boundary of the Middle Riphean in BMA. The $\varepsilon N d$ value for rapakivi granites ranges from -5.0 to -7.3 and indicates a significant role of the crustal component in a melt source [Larin, 2011]. As for gabbro, the presence of depleted mantle material $\left(\mathrm{I}_{\mathrm{sr}}=0.7032\right)$ in the substrate is suggested [Gorozhanin, 1998].

The Akhmerovo granite massif is located in the eastern edge of BMA among the Lower Riphean metasedimentary rocks and confined to the core of the Beloretsk structure. The Akhmerovo granites have high contents of $\mathrm{FeO}$ and $\mathrm{TiO}_{2}$, the total REE $>300$ ppm, 

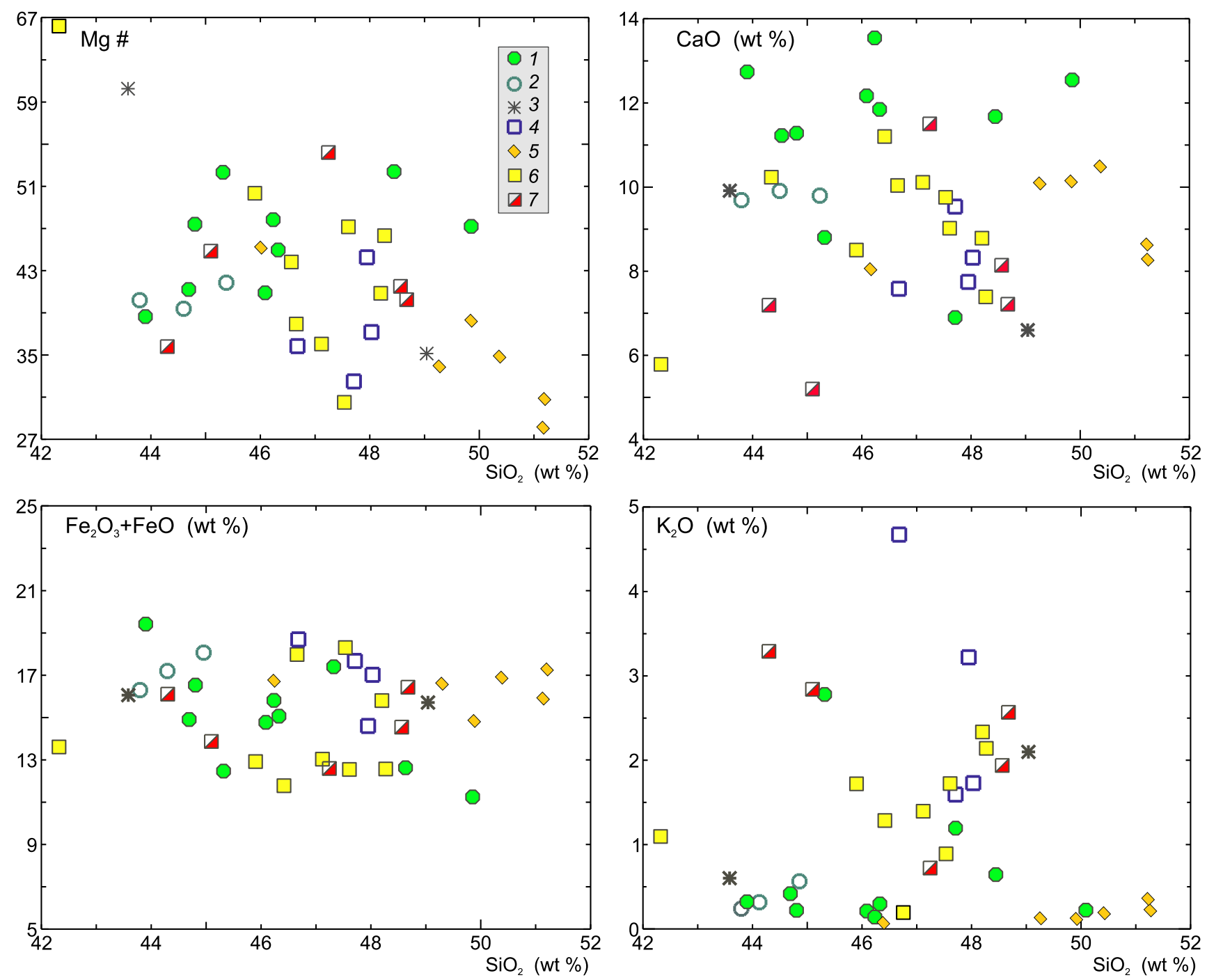

Fig. 4. Harker diagrams for gabbroids and dike rocks from BMA.

1-3 - gabbro from: 1 - Kusa-Kopan intrusion, 2 - borehole no. 2 (in the deep eastern part of the Kusa gabbro massif), 3 - Berdyaush pluton; 4-7 - dolerite dikes in: 4 - granites of the Gubenka massif, 5 - gabbro of the Kusa-Kopan intrusion, 6 - carbonate rocks of the Satka and Bakal Fms; 7 - metamorphic rocks of the Akhtensk block.

Рис. 4. Диаграммы Харкера для габброидов и дайковых пород БМА.

1-3 - габбро из: 1 - Кусинско-Копанской интрузии, 2 - скв. 2 (в западной части Кусинского массива габбро), 3 - Бердяушского плутона; 4-7 - дайки долеритов, секущие: 4 - граниты Губенского массива, 5 - габбро Кусинско-Копанской интрузии, 6 - карбонатные породы саткинской и бакальской свит; 7 - метаморфические породы Ахтенского блока.

$\mathrm{La} / \mathrm{Yb} 5-11$, and $\mathrm{Eu} / \mathrm{Eu}^{*}<1$. These features and the distribution of other trace elements ( $\mathrm{Sr}, \mathrm{Nb}$, and $\mathrm{Zr}$ ) are similar to those of rhyolites of the Mashak Fm. and granites of the Berdyaush pluton, indicating a withinplate setting. The geology details and the chemical composition are described in [Puchkov, 2012; Shardakova, 2016; etc.].

The SHRIMP-2 zircon age of granites of the Akhmerovo granite massif is $1381 \pm 23$ Ma [Krasnobaev et al., 2008]. The U-Pb (CA-ID-TIMS) zircon age of metabasalts and rhyolites of the Mashak Fm. is nearly the same, 1380-1385 Ma.
The Kusa-Kopan group of gabbro-granite intrusions. This group of intrusions occurs as a $2-5 \mathrm{~km}$ wide NE-striking zone that is traced for a distance of about $80 \mathrm{~km}$ in the BMA northeastern part to the west and then to the south-west from the town of Zlatoust in the Southern Urals.

The Middle Riphean gabbro-granite intrusions in BMA are confined to a few faults (see Figs. 2, 3). The largest and easternmost Zyuratkul-Karatash (ZK) fault comprises layered gabbroids (from south to north: the Matkal, Kopan, Medvedevka and Kusa massifs) and overlapping (from the east) the Ryabinovka and 

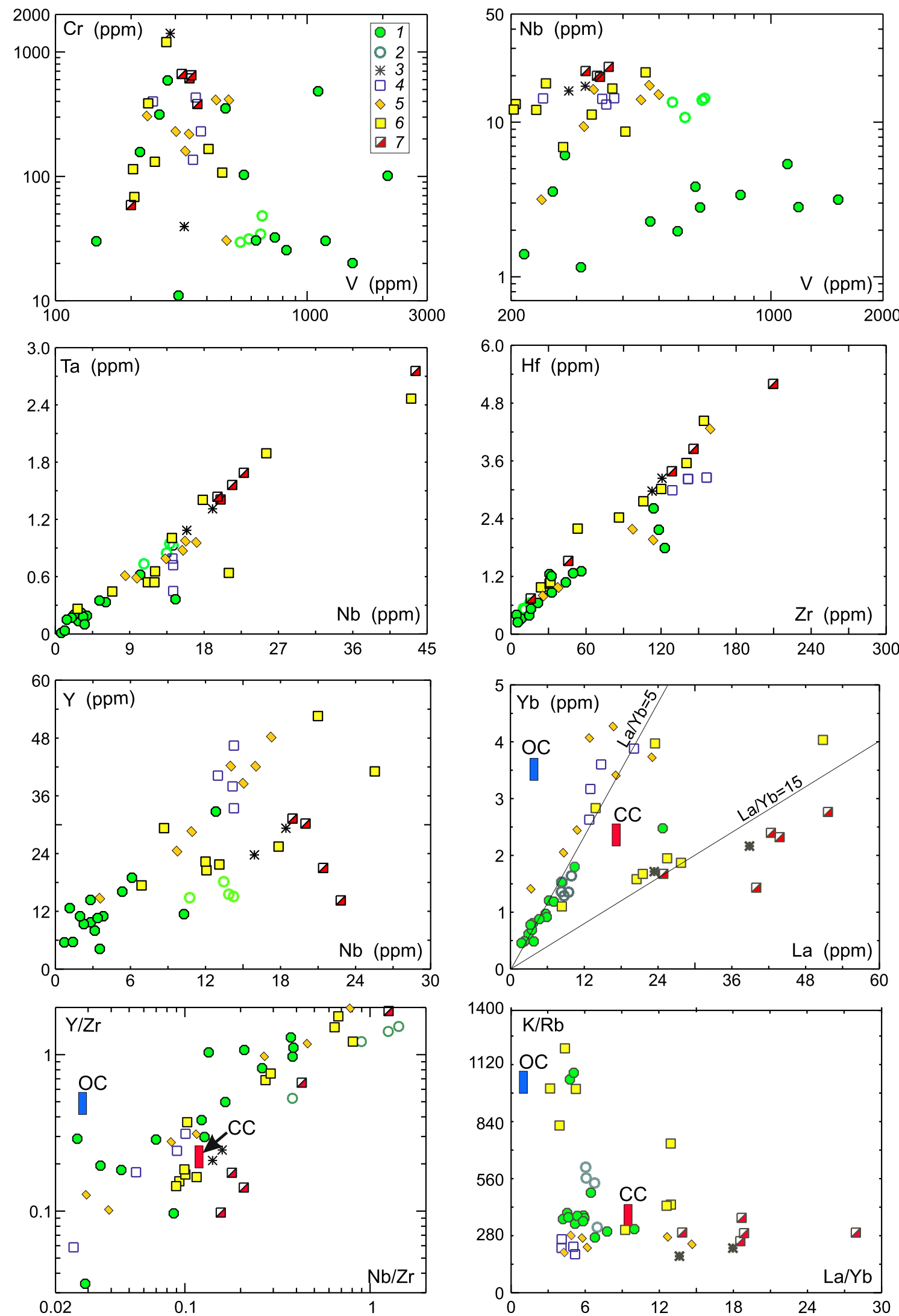

Fig. 5. Diagram of trace-element ratios for the rocks from BMA.

1-7 - see the legend in Fig. 3. OC and CC - compositions of the oceanic and continental types of crust, respectively.

Рис. 5. Диаграммы соотношений редких элементов в породах БМА.

1-7 - обозначения см. в подписи к рис. 3. ОС и СС - точки средних составов океанической и континентальной коры, соответственно. 
T a b l e 1. Contents of major (wt \%) and trace (ppm) elements in the representative samples of basalts from BMA

Т а б л и ц а 1. Содержания петрогенных (мас. \%) и рассеянных элементов (ppm) в представительных образцах базальтов БМА

\begin{tabular}{|c|c|c|c|c|c|c|c|c|c|}
\hline No. & 1 & 2 & 3 & 4 & 5 & 6 & 7 & 8 & 9 \\
\hline Sample & $05-05$ & $05-07$ & $18-01$ & $19-03$ & 24 (СЗК-51) & 2 & 3 & Ks-399 & ChG-1 \\
\hline $\mathrm{SiO}_{2}$ & 47.60 & 49.70 & 49.10 & 48.60 & 50.10 & 57.20 & 52.60 & 52.10 & 46.30 \\
\hline $\mathrm{TiO}_{2}$ & 2.60 & 2.60 & 1.90 & 1.40 & 1.40 & 2.00 & 0.60 & 1.30 & 1.10 \\
\hline $\mathrm{Al}_{2} \mathrm{O}_{3}$ & 14.90 & 13.40 & 12.20 & 13.10 & 13.50 & 7.70 & 13.70 & 11.80 & 14.90 \\
\hline $\mathrm{Fe}_{2} \mathrm{O}_{3}{ }^{*}$ & 14.70 & 14.80 & 15.60 & 14.40 & 13.40 & 9.00 & 3.80 & 15.80 & 12.90 \\
\hline MnO & 0.10 & 0.20 & 0.20 & 0.20 & 0.20 & 0.40 & 0.20 & 0.20 & 0.30 \\
\hline MgO & 4.80 & 4.10 & 5.60 & 7.00 & 6.00 & 3.10 & 0.60 & 5.60 & 9.20 \\
\hline $\mathrm{CaO}$ & 6.30 & 6.20 & 8.90 & 8.10 & 8.50 & 8.10 & 10.10 & 8.40 & 11.90 \\
\hline $\mathrm{Na}_{2} \mathrm{O}$ & 3.30 & 2.50 & 2.70 & 3.60 & 3.00 & 7.30 & 11.90 & 2.50 & 2.00 \\
\hline $\mathrm{K}_{2} \mathrm{O}$ & 0.90 & 2.60 & 0.30 & 0.00 & 0.00 & 0.80 & 0.00 & 0.10 & 0.30 \\
\hline $\mathrm{P}_{2} \mathrm{O}_{5}$ & 0.70 & 0.80 & 0.20 & 0.20 & 0.10 & 2.80 & 1.10 & 0.10 & 0.20 \\
\hline LOI & 3.10 & 3.00 & 2.10 & 2.40 & 3.20 & 1.80 & 5.70 & 1.40 & 1.00 \\
\hline Total & 98.90 & 99.70 & 98.90 & 99.00 & 99.30 & 100.10 & 100.20 & 99.50 & 100.10 \\
\hline $\mathrm{Rb}$ & 14.00 & 46.00 & 9.00 & 2.00 & 1.00 & 46.20 & 2.00 & 1.90 & 4.70 \\
\hline $\mathrm{Sr}$ & 597.00 & 682.00 & 157.00 & 165.00 & 184.00 & 3414.00 & 350.40 & 95.30 & 55.60 \\
\hline $\mathrm{Ba}$ & 959.00 & 1550.00 & 64.00 & 61.00 & 9.00 & 70.60 & 60.10 & 17.60 & 83.10 \\
\hline V & 231.00 & 228.00 & 411.00 & 355.00 & 327.00 & 102.00 & 5.20 & 283.90 & 190.50 \\
\hline $\mathrm{Cr}$ & 58.00 & 51.00 & 67.00 & 137.00 & 95.00 & 164.40 & 127.30 & 218.50 & 124.10 \\
\hline Co & 41.00 & 42.00 & 54.00 & 61.00 & 38.00 & 11.60 & 7.70 & 50.40 & 70.10 \\
\hline $\mathrm{Ni}$ & 62.00 & 39.00 & 66.00 & 84.00 & 56.00 & 58.20 & 6.90 & 97.70 & 132.60 \\
\hline $\mathrm{Cu}$ & 27.00 & 38.00 & 130.00 & 228.00 & 165.00 & 51.10 & 16.30 & 23.40 & 366.50 \\
\hline $\mathrm{Zn}$ & 134.00 & 145.00 & 134.00 & 161.00 & 106.00 & 760.80 & 797.50 & 88.70 & 240.10 \\
\hline $\mathrm{Ga}$ & 23.00 & 24.00 & 22.00 & 22.00 & 18.00 & 60.30 & 33.80 & 15.80 & 16.00 \\
\hline Y & 30.00 & 30.00 & 33.00 & 28.00 & 25.00 & 41.60 & 60.70 & 27.20 & 10.50 \\
\hline $\mathrm{Nb}$ & 16.00 & 17.00 & 16.00 & 10.00 & 9.00 & 344.70 & 753.30 & 5.80 & 0.50 \\
\hline $\mathrm{Ta}$ & 0.90 & 0.90 & 0.60 & 0.50 & 0.50 & 23.50 & 31.10 & 0.30 & 0.10 \\
\hline $\mathrm{Zr}$ & 182.00 & 205.00 & 137.00 & 108.00 & 92.00 & 136.90 & 562.00 & 28.10 & 4.70 \\
\hline Hf & 4.70 & 5.20 & 4.00 & 3.10 & 2.80 & 3.10 & 14.40 & 0.80 & 0.20 \\
\hline $\mathrm{U}$ & 0.50 & 0.70 & 0.40 & 0.30 & 0.30 & 4.80 & 20.80 & 0.20 & 0.10 \\
\hline Th & 2.50 & 3.40 & 1.80 & 1.30 & 1.40 & 903.70 & 44.40 & 0.80 & 0.20 \\
\hline $\mathrm{La}$ & 36.70 & 48.50 & 14.30 & 14.30 & 11.90 & 551.60 & 92.80 & 6.20 & 3.20 \\
\hline $\mathrm{Ce}$ & 82.00 & 105.00 & 33.00 & 32.00 & 26.80 & 992.50 & 228.70 & 15.30 & 8.90 \\
\hline $\operatorname{Pr}$ & 10.00 & 12.10 & 4.30 & 4.00 & 3.30 & 93.50 & 34.60 & 2.20 & 1.20 \\
\hline $\mathrm{Nd}$ & 42.00 & 51.70 & 19.20 & 17.70 & 14.80 & 273.60 & 119.40 & 10.60 & 5.50 \\
\hline Sm & 8.40 & 9.90 & 5.00 & 4.10 & 3.80 & 48.10 & 25.30 & 3.00 & 1.50 \\
\hline $\mathrm{Eu}$ & 2.90 & 3.30 & 1.70 & 1.40 & 1.40 & 12.10 & 6.70 & 1.00 & 0.80 \\
\hline $\mathrm{Gd}$ & 7.70 & 8.40 & 5.90 & 4.70 & 4.30 & 35.10 & 19.60 & 3.70 & 1.90 \\
\hline $\mathrm{Tb}$ & 1.20 & 12.00 & 1.00 & 0.80 & 0.80 & 3.30 & 2.90 & 0.60 & 0.30 \\
\hline Dy & 5.90 & 6.40 & 6.20 & 5.10 & 4.70 & 13.00 & 16.40 & 4.30 & 2.20 \\
\hline Но & 1.10 & 1.20 & 1.20 & 1.00 & 0.90 & 1.80 & 2.80 & 0.90 & 0.50 \\
\hline $\mathrm{Er}$ & 3.10 & 3.50 & 3.70 & 3.10 & 2.80 & 3.90 & 6.70 & 2.70 & 1.40 \\
\hline $\mathrm{Tm}$ & 0.40 & 0.50 & 0.60 & 0.50 & 0.40 & 0.50 & 0.80 & 0.40 & 0.20 \\
\hline $\mathrm{Yb}$ & 2.80 & 2.90 & 3.60 & 3.00 & 2.70 & 3.60 & 4.10 & 2.60 & 1.40 \\
\hline $\mathrm{Lu}$ & 0.40 & 0.40 & 0.50 & 0.40 & 0.40 & 0.50 & 0.50 & 0.40 & 0.20 \\
\hline
\end{tabular}

N o t e. 1-7 - basalts: 1-2 - Ai Fm, 3-5 - Mashak Fm, 6-7 - Sibirka deposit; 8-9 - Nazyam amphybolites (metabasalts). * - Total Fe as Fe ${ }_{2} \mathrm{O}_{3}$.

П р и м е ч а н и е. 1-7 - базальты: 1-2 - айская свита, 3-5 - машакская свита, 6-7 - месторождение Сибирка; 8-9 - назямские амфиболиты (метабазальты). * - все железо приведено в форме $\mathrm{Fe}_{2} \mathrm{O}_{3}$.

Gubenka granite massifs with distinct tectonic contacts, constituting the Kusa-Kopan gabbro-granite group.

The results of chemical analysis for the Kusa-Kopan group are given in Table 2. Gabbroids are characterized by a smaller $\mathrm{SiO}_{2}$ content in contrast to all other Middle Riphean mafic rocks. This is reflected in slightly higher $\mathrm{MgO}$ and $\mathrm{CaO}$ contents, low contents of $\mathrm{K}_{2} \mathrm{O}, \mathrm{Rb}$, as well as most of highly charged elements, such as $\mathrm{Nb}, \mathrm{Ta}, \mathrm{Zr}$,
Hf, Y (Figs. 4, 5). A specific group of rocks is represented by ilmenite-bearing gabbro-norites penetrated by borehole no. 2 located to the east of the Kusa deposit. This type of gabbro-norite is characterized by high contents of $\mathrm{Nb}$ and $\mathrm{Ta}$, while, according to the concentrations of other incompatible elements, it is close to other gabbroids of the Kusa-Kopan group. A high $\mathrm{V}$ content in all the gabbro is due to accumulation of V-rich 
$\mathrm{T}$ a b l e 2. Content of major (wt \%) and trace (ppm) elements in the representative samples of gabbro and granites from BMA

Т а б л и ц а 2. Содержания петрогенных (мас. \%) и рассеянных элементов (pрm) в представительных образцах габбро и гранитов БМА

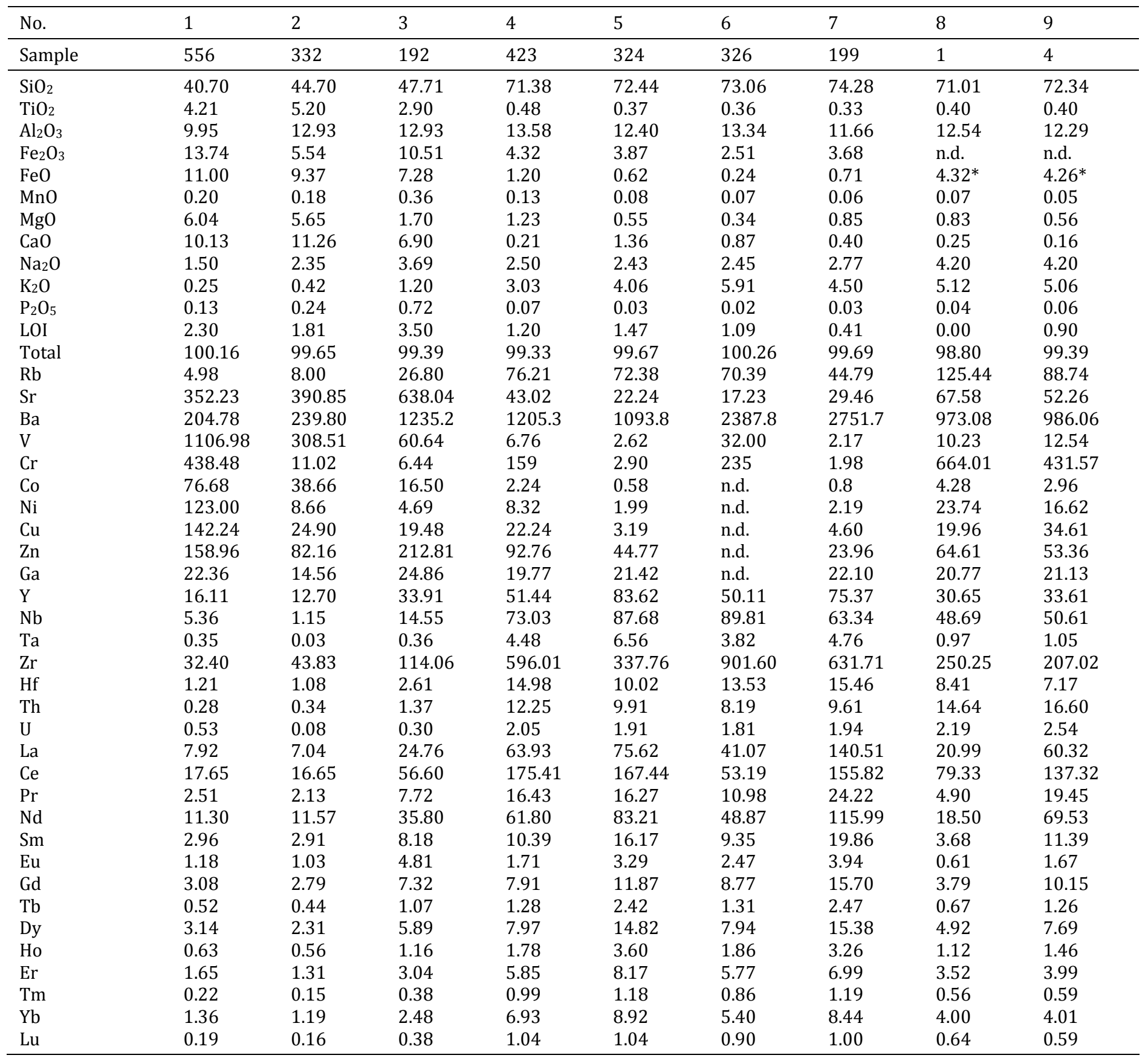

N o t e. 1-4 - Kopan massif: 1 - gabbro-norite, 2-3 - hornblende gabbro; 4-7 - granites of the Ryabinovka massif; 8-9 - granites of the Akhmerovo massif. n.d. - not determined.

П р и м е ч а н и е. 1-4 - Копанский массив: 1 - габбро, 2-3 - амфиболовое габбро; 4-7 - граниты Рябиновского массива; 8-9 граниты Ахмеровского массива. n.d. - не определялось.

magnetite and titanomagnetite ores. According to [Fershtater et al., 2001, 2005; etc.], this is an evidence of a high oxygen fugacity during their formation.

The granites of the Ryabinovka and Gubenka massifs have high content of $\mathrm{Fe}, \mathrm{Ti}$, total REE, and deep negative Eu-anomaly. The geochemistry of these granites is consistent with a continental rift setting.

The gabbro-granite massifs of the Kusa-Kopan group were formed at different depth levels. In the north, the emplacement of Kusa and Gubenka massifs 
$\mathrm{T}$ a b l e 3. Contents of major (wt \%) and trace (ppm) elements in the representative samples of rocks from the mafic sill-and-dike complex of BMA

Т а б л и ц а 3. Содержания петрогенных (мас. \%) и рассеянных (РРМ) элементов в представительных образцах базитов силлово-дайкового комплекса БМА

\begin{tabular}{|c|c|c|c|c|c|c|c|c|c|}
\hline \multirow[t]{2}{*}{ No. } & 1 & 2 & 3 & 4 & 5 & 6 & 7 & 8 & 9 \\
\hline & 523 & 531 & 540 & 181 & B3 & 155 & 314 & 171 & 319 \\
\hline $\mathrm{SiO}_{2}$ & 48.68 & 45.10 & 48.20 & 47.53 & 43.58 & 47.71 & 46.68 & 51.19 & 46.66 \\
\hline $\mathrm{TiO}_{2}$ & 3.03 & 2.47 & 1.57 & 3.25 & 1.71 & 2.18 & 2.02 & 2.51 & 1.21 \\
\hline $\mathrm{Al}_{2} \mathrm{O}_{3}$ & 11.11 & 14.58 & 10.93 & 10.11 & 8.83 & 10.84 & 10.82 & 10.83 & 12.47 \\
\hline $\mathrm{Fe}_{2} \mathrm{O}_{3}$ & 7.73 & 4.27 & 4.7 & 3.05 & 6.96 & 10.74 & 10.84 & 3.27 & 8.85 \\
\hline $\mathrm{FeO}$ & 8.70 & 9.60 & 11.10 & 15.26 & 9.10 & 6.94 & 7.85 & 12.48 & 9.37 \\
\hline $\mathrm{MnO}$ & 0.21 & 0.09 & 0.17 & 0.22 & 0.21 & 0.26 & 0.31 & 0.21 & 0.16 \\
\hline $\mathrm{MgO}$ & 5.92 & 6.13 & 5.94 & 4.44 & 13.07 & 4.49 & 5.52 & 3.88 & 5.94 \\
\hline $\mathrm{CaO}$ & 7.21 & 5.20 & 8.79 & 9.76 & 9.92 & 9.54 & 7.58 & 8.62 & 10.17 \\
\hline $\mathrm{Na}_{2} \mathrm{O}$ & 2.70 & 2.40 & 2.5 & 2.55 & 1.85 & 3.39 & 1.20 & 3.69 & 2.27 \\
\hline $\mathrm{K}_{2} \mathrm{O}$ & 2.57 & 2.84 & 2.34 & 0.89 & 0.60 & 1.59 & 4.67 & 0.27 & 0.23 \\
\hline $\mathrm{P}_{2} \mathrm{O}_{5}$ & 0.36 & 0.48 & 0.20 & 0.42 & 0.28 & 0.26 & 0.25 & 0.31 & 0.09 \\
\hline LOI & 2.06 & 7.50 & 2.55 & 1.98 & 3.54 & 1.76 & 1.96 & 1.64 & 1.7 \\
\hline Total & 100.28 & 100.66 & 98.97 & 99.46 & 99.66 & 99.70 & 99.71 & 98.9 & 99.13 \\
\hline $\mathrm{Li}$ & 15.01 & 31.13 & 37.76 & n.d. & 73.52 & n.d. & n.d. & n.d. & n.d. \\
\hline $\mathrm{Rb}$ & 71.03 & 54.05 & 58.06 & 22.38 & 23.43 & 42.51 & 172.93 & 2.31 & 0.94 \\
\hline Cs & 1.92 & 1.98 & 2.81 & 0.96 & 0.75 & 0.50 & 2.35 & 0.04 & 0.01 \\
\hline $\mathrm{Sr}$ & 344.5 & 87.90 & 225.70 & 221.1 & 241.00 & 281.70 & 132.90 & 167.00 & 241.60 \\
\hline $\mathrm{Ba}$ & 515.9 & 1616.6 & 259.20 & 209.7 & 213.30 & 494.80 & 983.90 & 67.00 & 127.30 \\
\hline Sc & 22.11 & 22.36 & 45.79 & 37.72 & 33.76 & n.d. & n.d. & n.d. & n.d. \\
\hline V & 341.00 & 199.80 & 406.10 & 460.00 & 286.00 & 361.00 & 379.00 & 482.00 & 240.00 \\
\hline $\mathrm{Cr}$ & 614.30 & 58.90 & 166.30 & 107.50 & 1411.70 & 430.00 & 230.00 & 405.00 & 312.00 \\
\hline $\mathrm{Ni}$ & 171.80 & 22.80 & 81.60 & 74.10 & 414.60 & n.d. & n.d. & n.d. & n.d. \\
\hline $\mathrm{Cu}$ & 29.70 & 67.80 & 166.30 & 182.30 & 74.20 & n.d. & n.d. & n.d. & n.d. \\
\hline $\mathrm{Zn}$ & 191.6 & 120.20 & 138.90 & 152.00 & 220.40 & n.d. & n.d. & n.d. & n.d. \\
\hline Y & 30.22 & 29.64 & 29.29 & 52.58 & 23.73 & 40.21 & 46.43 & 47.52 & 14.16 \\
\hline $\mathrm{Nb}$ & 20.00 & 43.59 & 8.70 & 21.00 & 15.92 & 13.00 & 14.28 & 17.09 & 3.30 \\
\hline $\mathrm{Ta}$ & 1.41 & 2.76 & 0.63 & 0.64 & 1.09 & 12.67 & 0.72 & 0.93 & 0.25 \\
\hline $\mathrm{Zr}$ & 15.90 & 209.70 & 86.40 & 31.00 & 112.90 & 129.00 & 262.00 & 464.20 & 115.60 \\
\hline $\mathrm{Hf}$ & 0.75 & 5.20 & 2.42 & 1.05 & 2.97 & 2.99 & 3.92 & 6.26 & 1.99 \\
\hline $\mathrm{Pb}$ & 8.90 & 0.94 & 6.88 & 3.02 & 27.22 & 8.09 & 33.13 & 3.41 & 3.14 \\
\hline $\mathrm{U}$ & 0.74 & 1.12 & 0.27 & 0.68 & 0.36 & 1.66 & 2.07 & 1.70 & 1.00 \\
\hline $\mathrm{Th}$ & 4.44 & 4.69 & 1.11 & 2.75 & 1.61 & 9.02 & 4.87 & 9.84 & 3.70 \\
\hline $\mathrm{La}$ & 43.17 & 51.63 & 13.03 & 23.51 & 23.38 & 13.00 & 20.10 & 16.78 & 3.02 \\
\hline $\mathrm{Ce}$ & 89.59 & 104.29 & 29.12 & 58.50 & 40.54 & 34.72 & 100.87 & 38.35 & 18.83 \\
\hline $\operatorname{Pr}$ & 11.84 & 12.65 & 4.08 & 7.67 & 6.42 & 5.01 & 6.79 & 5.21 & 1.31 \\
\hline $\mathrm{Nd}$ & 48.14 & 48.97 & 17.52 & 33.75 & 27.11 & 25.9 & 34.17 & 26.43 & 7.50 \\
\hline $\mathrm{Sm}$ & 9.48 & 8.61 & 4.40 & 8.55 & 5.48 & 6.28 & 8.01 & 5.80 & 2.12 \\
\hline $\mathrm{Eu}$ & 2.66 & 2.53 & 1.44 & 2.22 & 1.72 & 1.87 & 2.33 & 1.66 & 0.62 \\
\hline $\mathrm{Gd}$ & 7.91 & 7.27 & 4.53 & 9.14 & 5.13 & 7.34 & 9.50 & 7.67 & 2.68 \\
\hline $\mathrm{Tb}$ & 1.15 & 1.11 & 0.78 & 1.44 & 0.74 & 1.15 & 1.34 & 1.26 & 0.43 \\
\hline Dy & 6.24 & 5.77 & 5.01 & 8.35 & 4.20 & 6.34 & 7.37 & 7.21 & 2.57 \\
\hline Ho & 1.14 & 1.13 & 1.10 & 1.82 & 0.83 & 1.31 & 1.55 & 1.60 & 0.54 \\
\hline $\mathrm{Er}$ & 2.77 & 2.92 & 2.97 & 4.77 & 2.05 & 3.77 & 4.50 & 4.68 & 1.57 \\
\hline $\mathrm{Tm}$ & 0.38 & 0.44 & 0.45 & 0.63 & 0.29 & 0.54 & 0.66 & 0.69 & 0.23 \\
\hline $\mathrm{Yb}$ & 2.33 & 2.77 & 2.68 & 3.97 & 1.72 & 3.17 & 3.88 & 4.27 & 1.38 \\
\hline $\mathrm{Lu}$ & 0.31 & 0.44 & 0.37 & 0.53 & 0.27 & n.d. & n.d. & n.d. & n.d. \\
\hline
\end{tabular}

N o t e. Dykes from: 1-2 - Akhtensk complex; 3-4 - Satka Fm; 5 - Berdyaush massif; 6-7 - Gubenka massif; 8 - Medvedevka massif; 9 Kopan massif. n.d. - not determined.

П р и м е ч а н и е. Дайки в породах: 1-2 - ахтенского комплекса; 3-4 саткинской свиты; 5 - Бердяушского массива; 6-7 - Губенского массива; 8 - Медведевского массива; 9 - Копанского массива. n.d. - не определялось.

occurred under conditions of abyssal depth facies at the pressures of 6-8 kbar and more. In the south, the total and fluid pressure during formation of less deep gabbro and granitoid intrusions (Kopan and Ryabinovka mas- sifs) was reduced to 1-3 kbar. A total difference in the formation depth between gabbro-granite intrusions in the north and south of the Kuvash graben and the ZK fault is up to $\sim 20 \mathrm{~km}$ [Fershtater et al., 2001, 2005]. 
The Kusa-Kopan group of intrusions has been recently studied in great detail using the isotope method [Kholodnov et al., 2006, 2010; Kholodnov, Shagalov, 2012; etc.]. The isotopic age data obtained with $\mathrm{U}-\mathrm{Pb}, \mathrm{Sm}-\mathrm{Nd}$, and $\mathrm{Rb}-\mathrm{Sr}$ methods indicate that the ages of ore-bearing gabbroids of the Kusa-Kopan group and the Gubenka and Ryabinovka granite massifs overlying them in the east, lie in the same range of 1385-1395 Ma. The Sm-Nd age of gabbro-norites of the Kusa deposit is $1388 \pm 63$ $\mathrm{Ma}$; that of vein-like massive magnetite-ilmenite ores of this deposit is $1392 \pm 130 \mathrm{Ma}$. Similar Sm-Nd zircon ages were obtained for gabbro-norites of the southern Kopan massif and granitoids of their comagmatic Ryabinovka massif $(1385 \pm 25 \mathrm{Ma})$; anorthosite from rhythmically layered unit of ore-bearing rocks of the Medvedevka deposit yielded an age of $1379 \pm 8 \mathrm{Ma}$. The $\mathrm{Rb}-\mathrm{Sr}$ isotopic age data obtained for granitoids of the Ryabinovka and Gubenka massifs are as follows: the Ryabinovka massif (1394 Ma, ${ }^{87} \mathrm{Sr} /{ }^{86} \mathrm{Sr}_{\mathrm{i}}=0.705485 \pm 0.000034$ ); the Gubenka massif (1388.5 Ma, $\left.{ }^{87} \mathrm{Sr} /{ }^{86} \mathrm{Sr}_{\mathrm{i}}=0.70570 \pm 0.00012\right)$. Thus, owing to the variety of isotope methods used, we were able to reliably establish that gabbroids, granitoids, and the ores of the Kusa-Kopan complex formed in a similar age range, namely, at the beginning of the Middle Riphean. A few granite porphyry dikes intruded the Medvedevka deposit a bit later: 1353 \pm 16 Ma [Kholodnov, Shagalov, 2012].

Sill-and-dike complex. The study of the isotope systematics of sill-and-dike swarms, widely developed in BMA, is problematic due to a lack of age data. Currently, there are only a few reliable isotope age datings. The $\mathrm{U}-\mathrm{Pb}$ baddeleyite age of dolerites of the Main Dike of the Bakal ore field age is $1385.3 \pm 1.4 \mathrm{Ma}$ [Ernst et al., 2006]. Picrobasalts and picrites of the sill-like bodies of the Taratash block and picrobasalts from the exocontact zone of the Kusa intrusive massif have similar age datings [Nosova et al., 2012]. In terms of geochronology, these subvolcanic bodies were formed synchronously with other Middle Riphean intrusive and volcanic formations of BMA.

In addition, there are younger dolerite dikes in different parts of BMA. For example, a swarm of sublatitudinal dikes crossing stratified gabbroid intrusions of the Kusa-Kopan ore-bearing complex, elongated along the ZK fault. Dikes in the southern shallow massifs (Kopan and Matkal) have chilled contact zones. They are usually not metamorphosed and represented by fine-grained equigranular, porphyritic rocks with ophitic texture. In the deep northern Kusa intrusion, late dikes have no chilled zones; they often occur in endocontact zones and foliated and tectonically deformed gabbro. This gives evidence that those dikes intruded after one of the phases of tectonic deformation. Among the granite-gneisses of the Gubenka massif, sheets of orthoamphibolites, concordant with the surrounding rocks, are present. All of these bodies are boudinaged to varying extents. Dikes in the Berdyaush massif are represented by amphiboledolerite. They cut intrusive rocks and enclosing deformed dolomites of the Satka Fm. and have chilled contacts with them.

The mafic rocks of the sill-dike swarms have similarities and differences in composition. A common feature of all these groups of mafic rocks is higher contents of $\mathrm{Fe}, \mathrm{V}$ and $\mathrm{Ti}$ (Table 3), which are considerably higher than their average contents in traps and basalts of continental rifts. According to the content of potassium and incoherent trace elements (Figs. 4, 5), they are very different and subdivided into three groups.

(I) Dike rocks, intersecting the Lower Proterozoic rocks of the Aleksandrovsk-Akhtensk metamorphic block are characterized by the highest contents of $\mathrm{K}_{2} \mathrm{O}$ (up to 3 wt \%), lithophilic and the highly charged trace elements (Rb, Ba, P, Ti, $\mathrm{Nb}, \mathrm{Ta}, \mathrm{La}, \mathrm{Ce}, \mathrm{Hf}$, and $\mathrm{Zr}$ ), and $\mathrm{Cr}$, as well as high $\mathrm{La} / \mathrm{Yb}(15-20)$ and low (300) K/Rb ratios.

(II) Hornblende, olivine gabbro-dolerite and dolerites dikes, sills of two-pyroxene gabbro in carbonate rocks of the Satka and Bakal formations are characterized by lower contents of $\mathrm{K}_{2} \mathrm{O}$ (1-2.5 wt \%), $\mathrm{Rb}, \mathrm{Ba}, \mathrm{P}$, $\mathrm{Nb}$ and other incoherent rare elements, a lower $\mathrm{La} / \mathrm{Yb}$ ratio (5-10) against the background of increasing $\mathrm{K} / \mathrm{Rb}$ ratio (Fig. 5).

(III) The latest sublatitudinal dolerite dikes crosscutting the intrusive rocks of the Kusa-Kopan intrusion are characterized by a low alkalinity, low contents of $\mathrm{K}_{2} \mathrm{O}$ (0.20-0.30 wt \%), and $\mathrm{Rb}, \mathrm{Cs}, \mathrm{Ba}, \mathrm{P}, \mathrm{Nb}, \mathrm{La}$, and $\mathrm{Ce}$ (see Table 3), the lowest $\mathrm{La} / \mathrm{Yb}$ ratio (2-4) at high $\mathrm{K} / \mathrm{Rb}$ ratio (1000-2000). On spidergrams (Fig. 6) the latest dikes have sharp minimums of $\mathrm{K}, \mathrm{Rb}, \mathrm{Sr}$, and $\mathrm{Zr}$, and positive anomalies of $\mathrm{Sc}, \mathrm{V}, \mathrm{Li}$, and $\mathrm{Ba}$. On the chondrite-normalized REE distribution diagram (Fig. 6), the points of dikes of this group form a unified field with metavolcanics of the Nazyam sequence. In contrast to the other Middle Riphean rocks, they are characterized by the high HREE contents against the background of low LREE contents.

There are the following isotope datings. The age of dolerite sill at the outskirts of the Kusa town is $1360 \pm 9$ Ma (Ar-Ar method) [Puchkov, 2012]. According to [Nosova et al., 2012], the low-Ti mafic rocks (picrites and dolerites) formed in BMA somewhat later (1320 Ma) than the high-Ti mafic rocks (1385 Ma). In addition, there is the only $\mathrm{Sm}-\mathrm{Nd}$ isochron age dating $(1291 \pm 67 \mathrm{Ma})$ obtained for picrites of the Ishlya complex (i.e. the central part of the BMA] [Sazonova et al., 2011].

Thus, the above isotopic age data suggest that the gabbro-granitoid intrusions and several crosscutting dikes formed almost synchronously with the bimodal basalt-rhyolite volcanism at the Mashak complex. The magnesite deposits formed in the Lower Riphean deposits of the Satka Fm. (1380 $\pm 14 \mathrm{Ma}, \mathrm{U}-\mathrm{Pb}$ method) 

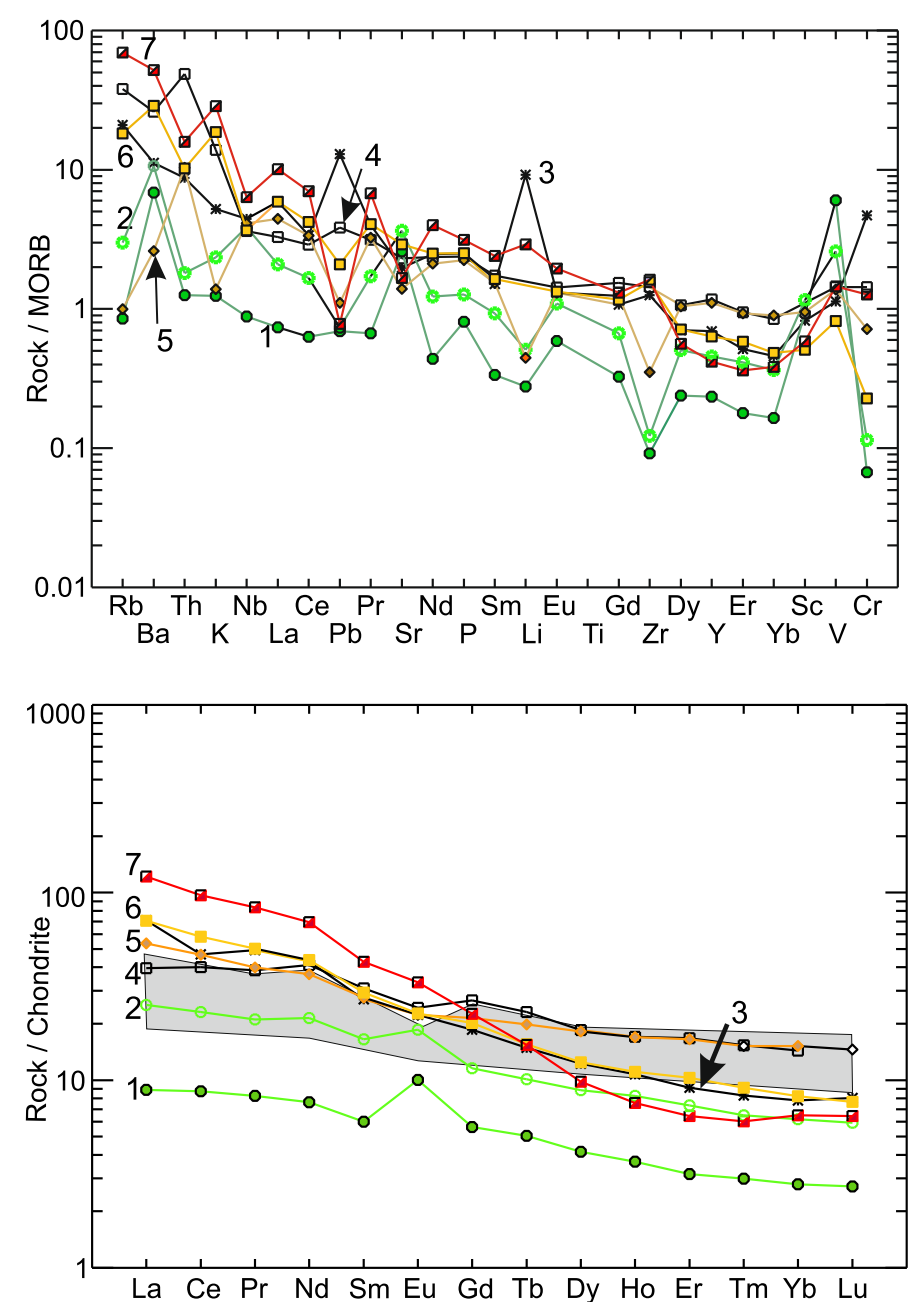

[Ovchinnikova et al., 2014]. All these igneous and metasomatic rocks recorded episodes of rifting during the Mashak event in their composition and textural-structural features [Maslov et al., 1997].

Trachybasalts and andesitic basalts of the Sibirka deposit. The Sibirka rare metal deposit is located on the left bank of the Satka River, near the Sibirka village (Chelyabinsk Region). Despite the deposit containing the mineable contents of $\mathrm{Nb}, \mathrm{Ta}, \mathrm{Zr}$, Th, and Mo, it is assigned to a noncommercial type due to poor ore washability. It is confined to a small circular volcanic structure in a feathering fault associated with the ZK fault. The ore-bearing rocks are feldspathic, feldspathoid-feldspathic, and carbonatite metasomatic rocks developed after basaltic trachyandesites. Sometimes, the latter look like eruptive breccia and contain xenoliths of felsic rocks which are similar in mineral and chemical composition to granites of the Ryabinovka massif, located north-east, also in the fault zone. The central part of the volcanic structure is occupied by more siliceous rocks, namely biotite-microcline syenites (often albitized, hematitized, and silicified) which are attributed to the end members of magmatic series.
Fig. 6. MORB- and chondrite-normalized [Sun, 1982] REEpatterns for the Mesoproterozoic rocks from BMA.

The numbers on the diagrams correspond to those in Fig. 4. Nazyam metabasalts and the youngest dikes crosscutting the gabbro of the Kusa-Kopan group are shown as a separate field in the lower figure.

Рис. 6. Нормированное по БСОХ и хондриту [Sun, 1982] распределение редких элементов в мезопротерозойских породах БМА.

Номера см. на рис. 4. Отдельным полем в нижней части рисунка показаны назямские метабазальты и самые молодые дайки, секущие габбро Кусинско-Копанской интрузии.

Alkaline metasomatic rocks contain biotite, aegerine, alkaline amphibole, and hematite; there is a metasomatic zoning in the distribution of minerals. The finegrained rare-metal mineralization (columbite, pyrochlore, Nb-aeschynite, molybdenite, thorite, etc.) is associated with the metasomatic rocks resulting from hydrothermal-metasomatic alteration of volcanic rocks which intruded the sedimentary rocks of the Bakal and Satka Formations. The data on the composition, structure, and mineralogy of ores are given in [Zoloev et al., 2004].

The Sibirka trachybasalts and basalts are ascribed to a specific petrogeochemical type of the BMA rocks. They are characterized by the highest contents of alkalis ( $\mathrm{K}$ and $\mathrm{Na}$ ), Ti, $\mathrm{P}$ and some trace elements $(\mathrm{Nb}, \mathrm{Ta}, \mathrm{U}$, Th, TR, Zr) (see Table 1). The cause of these petrochemical features is probably geochemical specifics of the parental magma, complex mechanism of generation and subsequent metasomatic processes.

We have obtained new isotope-geochronological data characterizing the early development period of the Sibirka deposit. The concordant age of one of the zircon associations extracted from the amphibole-biotite granite xenolith in trachybasaltic eruptive breccia is $1354 \pm 7$ Ma [Shagalov et al., 2014] that corresponds to 
T a b l e 4. Sm-Nd isotopic compositions of the rocks sampled from the Sibirka deposit and the adjacent intrusive complexes

T а б л и ц а 4. Изотопный состав $\mathrm{Sm}$ и $\mathrm{Nd}$ в породах месторождения Сибирка и сопутствующих интрузивных комплексов

\begin{tabular}{|c|c|c|c|c|c|c|c|c|}
\hline No. & $\mathrm{Sm}, \mathrm{ppm}$ & $\mathrm{Nd}, \mathrm{ppm}$ & ${ }^{147} \mathrm{Sm} /{ }^{144} \mathrm{Nd}$ & $\pm 2 \sigma, \%$ & ${ }^{143} \mathrm{Nd} /{ }^{144} \mathrm{Nd}$ & $\pm 2 \sigma, \%$ & $\varepsilon N d(T)^{*}$ & T-DM \\
\hline Sib-1 & 163.18 & 1455.33 & 0.06779 & 0.010 & 0.511630 & 0.000852 & 2.8 & 1437 \\
\hline Sib-2 & 47.77 & 372.96 & 0.07743 & 0.025 & 0.511824 & 0.001454 & 4.9 & 1316 \\
\hline Sib-3 & 25.70 & 125.66 & 0.12366 & 0.007 & 0.512196 & 0.000903 & 4.1 & 1366 \\
\hline Sib-4 & 11.59 & 66.71 & 0.10501 & 0.009 & 0.511956 & 0.001162 & 2.7 & 1475 \\
\hline Sib-5 & 18.43 & 109.35 & 0.10192 & 0.010 & 0.511994 & 0.001444 & 4.0 & 1377 \\
\hline Sib-6 & 52.99 & 269.09 & 0.11905 & 0.008 & 0.512147 & 0.001161 & 4.0 & 1379 \\
\hline Sib-7 & 40.02 & 187.14 & 0.12930 & 0.006 & 0.512178 & 0.001053 & 2.8 & 1502 \\
\hline Sib-8 & 76.31 & 415.02 & 0.11116 & 0.010 & 0.512011 & 0.000896 & 2.7 & 1483 \\
\hline Sib-9 & 5.87 & 32.03 & 0.11081 & 0.017 & 0.512036 & 0.004614 & 3.2 & 1437 \\
\hline Sib-10/2 & 16.86 & 91.80 & 0.11101 & 0.006 & 0.511796 & 0.001205 & -1.5 & 1821 \\
\hline Sib-10/3 & 12.52 & 64.38 & 0.11754 & 0.005 & 0.512147 & 0.000700 & 1.1 & 1634 \\
\hline Sib-10/6 & 8.89 & 46.25 & 0.11624 & 0.011 & 0.511985 & 0.002126 & -1.6 & 1857 \\
\hline Sib-10/8 & 13.93 & 73.78 & 0.11418 & 0.007 & 0.511838 & 0.000810 & 2.8 & 1479 \\
\hline Sib-11/1 & 10.63 & 49.16 & 0.13067 & 0.007 & 0.512042 & 0.001142 & 1.6 & 1624 \\
\hline
\end{tabular}

N o t e. ${ }^{*}-\varepsilon N d(T)$ in the rocks of the Sibirka deposit was recalculated: 1360 Ma. T-DM - model age according to [De Paolo, 1981].

П р и м е ч а н и е. * - величина $\varepsilon N d(T)$ в породах месторождения Сибирка рассчитана на возраст 1360 млн лет. T-DM - модельный возраст по [De Paolo, 1981].

the terminal stage of the Middle Riphean granitoid magmatism (dike cutting the Medvedevka gabbro massif) within the ZK fault.

The Sm-Nd-isotope systematics (Table 4) is characterized by a number of erochronous dependencies. One of them is characteristic of trachybasaltic volcanics and some types of ore-bearing metasomatic rocks with a general age $1337 \pm 150 \mathrm{Ma},{ }^{143} \mathrm{Nd} /{ }^{144} \mathrm{Nd}=0.51111 \pm$ \pm 0.00011 , MSWD $=39$. Trachyandesites have the highest $\varepsilon N d$ values $(+4 \ldots+4.9)$ indicating their source within the depleted mantle.The highest $\varepsilon N d$ value of syenite is slightly lower $(+1.6 \ldots+2.8)$. The model $\mathrm{Nd}$ ages of the magmatic sources are in the range of 1316-1857 Ma.

In general, the beginning of formation of the Sibirka polychronous deposit (1337 Ma) is in agreement (within an error) with the $\mathrm{Rb}-\mathrm{Sr}$ dating $(1323 \pm 53 \mathrm{Ma})$ from [Nosova et al., 2009] for trachybasalts of this structure.

Amphibolites (metabasalts) of the Nazyam sequence. These volcanic rocks are the youngest ones cropping out in the northern Kuvash volcanic area. Until now, this sequence has not been included into any formation due to its unclear stratigraphic position. Amphybolites form a zone in the eastern part of this area separated by a tectonic fault zone from the rocks of the apical part of the Gubenka granite massif, $3 \mathrm{~km}$ to the NNE of the Zlatoust city. The Nazyam sequence was named after the submeridional Nazyam (Nazma) Ridge extending in the north of the town of Zlatoust (more than $10 \mathrm{~km}$ in length), where metavolcanics of this type were first described.

The thickness of metavolcanics in some areas of the sequence is $0.5-1.0 \mathrm{~km}$. To the east, metavolcanics are tectonically overthrusted by the Middle Riphean quartzites and schists of the Taganay Fm.

Amphibolites have a granolepidoblastic texture with the parallel orientation of elongated minerals and are made of almost entirely saussuritized plagioclase, altered amphibole, and epidote, as well as accessory minerals (apatite, leucoxene, and magnetite). The relicts of the structure and the mineral association suggest that the primary rocks corresponded to basalts. The Nazyam metabasalts, the youngest rocks of this stage, are characterized by the lowest $\mathrm{K}$ content $(0.10$ $0.20 \% \mathrm{~K}_{2} \mathrm{O}$ ) and associated trace elements (Rb, Cs, Ba, $\mathrm{Sr}, \mathrm{P}, \mathrm{Nb}, \mathrm{La}, \mathrm{Ce}$, etc.) and low $\mathrm{La} / \mathrm{Yb}$ ratio (2-3).

The $\mathrm{K}-\mathrm{Ar}$ age of $\mathrm{K}$-poor amphibole varying in the range of 1155-1254 Ma (Table 5) was obtained for the samples of the Nazyam metavolcanics. The dating of 1254 Ma may show the late age limit of the Nazyam metavolcanogenic sequence formation, as well as the age of epidote-amphibolite facies metamorphism. The age of the primary volcanogenic substrate can be more ancient, probably in the range of about $1250-1300 \mathrm{Ma}$. Acording to our $\mathrm{Sm}-\mathrm{Nd}$ isotopic data $(\varepsilon \mathrm{Nd}+3.7 \ldots+5.5)$ (Table 6), the mantle component part in the source was significant.

\section{DISCUSSION. INTERPRETATION OF GEOCHEMICAL AND ISOTOPE DATA, AND GEODYNAMIC SETTINGS}

The compositions of Middle Riphean igneous rocks and dike swarms in BMA, as well as the most typical intra-continental rift systems worldwide are charac- 
V.V. Kholodnov et al.: The Riphean magmatism preceding the opening of Uralian paleoocean...

$\mathrm{T}$ a b l e 5. K-Ar ages of hornblende (amphibole) from metabasalts of the Nazyam mountains*

T а б л и ц а 5. K-Ar возраст амфибола из метабазальтов Назямских гор*

\begin{tabular}{llll}
\hline Sample & K, \% & ${ }^{40}$ Ar, ng/g & Age, Ma \\
\hline KS 399/1(2005) & 0.18 & 20.2 & $1155 \pm 80$ \\
KS 399/2(2007) & 0.17 & 19.8 & 1178 \\
& & 21.6 & $1216 \pm 38$ \\
\hline
\end{tabular}

$\mathrm{N}$ o t e. * - The sample was collected from the Chernaya Mountain, $8.5 \mathrm{~km}$ to the west of the Zlatoust city, on the watershed near the Zlatoust-Magnitka road. The analysis was conducted at Centre Geoanalitik, IGG UB RAS (analysts A.I. Stepanov, and B.A. Kaleganov).

П р и м е ч а н и е. * - образцы отобраны на г. Черная Скала, 8.5 км западнее г. Златоуст, на водоразделе близ дороги ЗлатоустМагнитка. Анализы выполнены в ЦКП «Геоаналитик» ИГГ УрО РАН (аналитики А.И. Степанов и Б.А. Калеганов).

teristic of the chemical composition evolution of rocks: from early more alkaline and subalkaline ones to essentially depleted in $\mathrm{K}$ and non-coherent lithophylic rare elements ( see Tables 1 and 3). Separate sites of alkaline rocks still persist in the study area (Sibirka, Berdyaush).

In the plots of $\mathrm{Nb} / \mathrm{Yb}$ versus $\mathrm{Th} / \mathrm{Yb}$ (Fig. 7), the above-described rock associations form a major field, which is elongated along the mantle trend. Some of them are more alkaline rocks (the Sibirka trachybasalts, the Berdyaush mafic rocks, and dikes in the Aleksandrovsk-Akhtensk block) that are similar to the enriched rocks such as OIB-type.The other rocks (basalts of the Mashak Fm., gabbro-norites of the KusaKopan complex, late dikes in gabbro intrusions, dikes in rocks of the Satka Fm.) are attributed to E-MORB.The Nazyam amphibolites occupy the field between EMORB and N-MORB. All the spectra of above-described BMA rocks in the $\mathrm{Th} / \mathrm{Yb}-\mathrm{Nb} / \mathrm{Yb}$ coordinates closely match the rocks of the East African Rift and the Red Sea Rift (see Fig. 7) [Rogers, 1993; Volker et al., 1997; Barrat et al., 1998; etc.].

Having analyzed the published data and our isotopic and geochemical data on the Middle Riphean igneous rocks of BMA, we suggest that magmatic (mantle and crustal) sources varying in the composition could have been involved in the rift magmatism.
The area of the lowest $\varepsilon \mathrm{Nd}$ values is marked by the positions of the points (Fig. 8, a) of granite-rapakivi from the Berdyaush massif and dikes in the Aleksandrovsk-Akhtensk block (from -5.0 to -7.3 ). For comparison, the figure shows the field of sedimentary carbonate of the Satka Fm. (1550 Ma) containing typical riftogenic Satka magnesite deposits (1400 Ma) [Krupenin et al., 2016].

The lower right-hand part of the diagram (see Fig. 8, a) shows the position of the rocks of the Taratash complex (Archean) [Popov et al., 2002], which could be a part of the Kuvash-Mashak structure basement.

The massive magnetite-ilmenite ores of the Kusa deposit and the gabbro-norites of the Kopan massif from that structure are characterized by the lowest negative $\varepsilon N d$ values ( -1.1 and -2.4 , respectively). We note that the latter ones, together with the granites of the Ryabinovka and Gubenka massifs, have a higher initial ratio of ${ }^{87} \mathrm{Sr} /{ }^{86} \mathrm{Sr}(0.7050-0.7060)$. Probably, the mantle source for the rocks of the Kusa-Kopan group was metasomatically enriched by the crustal component. The volcanic members of the Middle Riphean sequence (basalts of the Mashak Fm.) also belong to the derivatives of poorly enriched mantle source $(\varepsilon N d+0.6 \ldots+0.8)$. The $\varepsilon N d$ values in the syenitoids of the Sibirka deposit (about +2 ), the gabbro xenoliths in the granites of the Berdyaush massif $(\varepsilon N d+4 \ldots+4.9)$

T a b l e 6.Sm- and Nd-isotope concentrations of metabasalts of the Nazyam mountains*

T а б л и ц а 6. Изотопный состав Sm и Nd в метабазальтах Назямских гор*

\begin{tabular}{lllllllll}
\hline No. & Sm, ppm & Nd, ppm & ${ }^{147} \mathrm{Sm} /{ }^{144} \mathrm{Nd}$ & $\pm 2 \sigma, \%$ & ${ }^{143} \mathrm{Nd} /{ }^{144} \mathrm{Nd}$ & $\pm 2 \sigma, \%$ & $\varepsilon N d, \mathrm{~T}$ & $\mathrm{~T}-\mathrm{DM}$ \\
\hline chg-1 & 2.56 & 9.09 & 0.17022 & 0.012 & 0.512702 & 0.00212 & +5.5 & 1570 \\
\hline chg-2 & 2.16 & 7.51 & 0.17374 & 0.008 & 0.512635 & 0.001731 & +3.7 & 1963 \\
\hline
\end{tabular}

N o t e. * - Specimens was collected from the Chernaya Mountain. The analysis was conducted at Centre Geoanalitik, IGG UB RAS. Analyst N.G. Soloshenko.

П р и м е ч а н и е. * - образцы отобраны на г. Черная Скала. Анализы выполнены в ЦКП «Геоаналитик» ИГГ УрО РАН (аналитик Н.Г. Солошенко). 


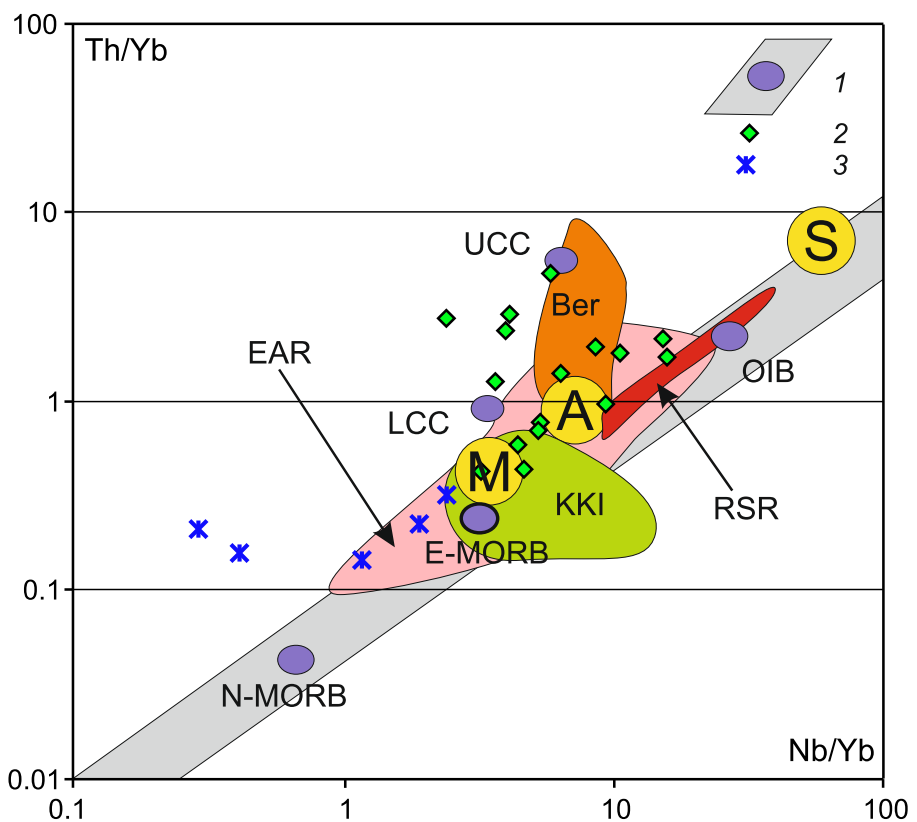

Fig. 7. Plots of $\mathrm{Nb} / \mathrm{Yb}$ versus $\mathrm{Th} / \mathrm{Yb}$ [Pearce, 2008] for magmatic rocks of BMA.

1 - mantle sequence and average composition points of the mantle (N-MORB, E-MORB, OIB) and crustal (UCC and LCC, Late and lower continental types of crust, correspondingly) sources; RSR Red Sea Rift [Rogers, 1993; Volker et al., 1997]; EAR - East African Rift [Deniel et al., 1994; Duffield et al., 1997; Barrat et al., 1998; Lowenstern et al., 2006; Daoud et al., 2010; Teklay et al., 2010; Field et al., 2012; Rooney et al., 2013]; 2 - sill-and-dike swarms; 3 -amphibolites (metabasallts) of the Nazyam mountains. Letters in circles mean the average compositions of basalts of Ai (A) and Mashak (M) formations, trachybasalts of the Sibirka deposit (S). The green and orange fields are gabbro-norites of the KusaKopan intrusion (KKI) and gabbro of the Berdyaush massif (Berd), respectively.

Рис. 7. Отношения $\mathrm{Nb} / \mathrm{Yb}$ - Th/Yb [Pearce, 2008] в магматических породах БМА.

1 - мантийная последовательность и точки средних составов мантийных (N-MORB, E-MORB, OIB) и коровых (UCC и LCC, верхняя и нижняя континентальная кора, соответственно) источников; RSR - Красноморский рифт [Rogers, 1993; Volker et al., 1997]; EAR - Восточно-Африканский рифт [Deniel et al., 1994; Duffield et al., 1997; Barrat et al., 1998; Lowenstern et al., 2006; Daoud et al., 2010; Teklay et al., 2010; Field et al., 2012; Rooney et al., 2013]; 2 - силлово-дайковые рои; 3 - амфиболиты (метабазальты) назямских гор. Буквы в кружках - средние составы базальтов айской (А) и машакской (M) свит, трахибазальтов месторождения Сибирка (S). Зеленым и оранжевым полями показана позиция габбро-норитов Кусинско-Копанской интрузии (KKI) and и габбро Бердяушского массива (Berd), соответственно.

indicate the participation of a depleted mantle component in the source. Maximal $\varepsilon N d$ values $(+3.7 \ldots+5.5)$ are revealed for the Nazyam metabasalts. Probably, the extension of the continental crust was the most intense in the northern area of the Kuvash-Mashak rift structure. The small Nazyam rift was formed, its bottom descended to a considerable depth, and almost complete break-up of the crust took place (Fig. 8, $b$ ). The mature pre-Riphean continental crust was transformed into a "suboceanic" type during the Lower and Middle Riphean. This process was illustrated in [Karsten et al., 1997] based on the analysis of the geochemistry of volcanic rocks of the Mashak Fm. These facts allow us to draw an analogy with the geodynamic conditions immediately preceding and accompanying the opening of rift structures and the beginning of spreading, for example, of the Afar branch of the East African Rift system. For comparison, Fig. 7 shows the points of the average composition of igneous rocks of the Red Sea Rift and the Gulf of Aden. In our case, there is no full section of the oceanic crust (or its fragments), as in the structures noted above. The existence of the Nazyam rift-graben was not very long. Apparently, the structure closed in the range of $1250-1150 \mathrm{Ma}$, possibly during one of the early stages of the Grenville activity; the nature of the latter in the Urals was discussed in [Krupenin, 2004; Maslov et al., 2014]. Starting from about $1200 \mathrm{Ma}$, from the east of EEP, the primary "rift-spreading" structures opened, and, subsequently, a large Riphean-Vendian oceanic basin was formed.

The synchronous involvement of different magmatic sources in the Middle Riphean riftogenic magmatism in BMA, the enriched mantle, the significantly depleted mantle (or with the crustal substance) seem to give evidence of penetration of a mantle plume into the lower part of the continental lithosphere, accompanied by partial melting and contaminationof the crustal substrate. The enrichment of mafic rocks with $\mathrm{Fe}$ and $\mathrm{Ti}$, HFSE, the presence in their composition of picrites (as well as dolerites) in sill-dike complexes, is an additional indicator that the Riphean riftogenic mafic rocks of BMA are related to the mantle plume.

Our data support the idea of R. Ernst [Ernst, 2014] and V. Puchkov [Puchkov, 2013] about the joint activity of plume- and plate-tectonic processes on the edge of the Columbia supercontinent. The rocks of the Middle Riphean sill-and-dike swarms and theintrusive and volcanic complexes of BMA formed a typical LIP due to the plume influence. It is known [Barrat et al., 1998; Puchkov, 2013; Ernst, 2014; Puchkov, 2016; etc.] that some igneous rocks in South America, Africa and China have a similar genesis and datings. So the members of this LIP are globally widespread. The plume initiated the beginning of intraplate rifting and, subsequently, the break-up of the continental crust (Nazyam rift, see Fig. 8, $b$ ).

For comparison, the $\varepsilon N d$ values for different in composition and genesis gabbro-ultramafic complexes of the eastern paleoceanic sector of the Urals, mainly from the Main Uralian Fault zone, are shown in the left corner of Fig. 8 (according to the literature). Then, the volcanics and granitoids of the western paleocontinental slope of the Northern, Middle and Southern Urals 
V.V. Kholodnov et al.: The Riphean magmatism preceding the opening of Uralian paleoocean...

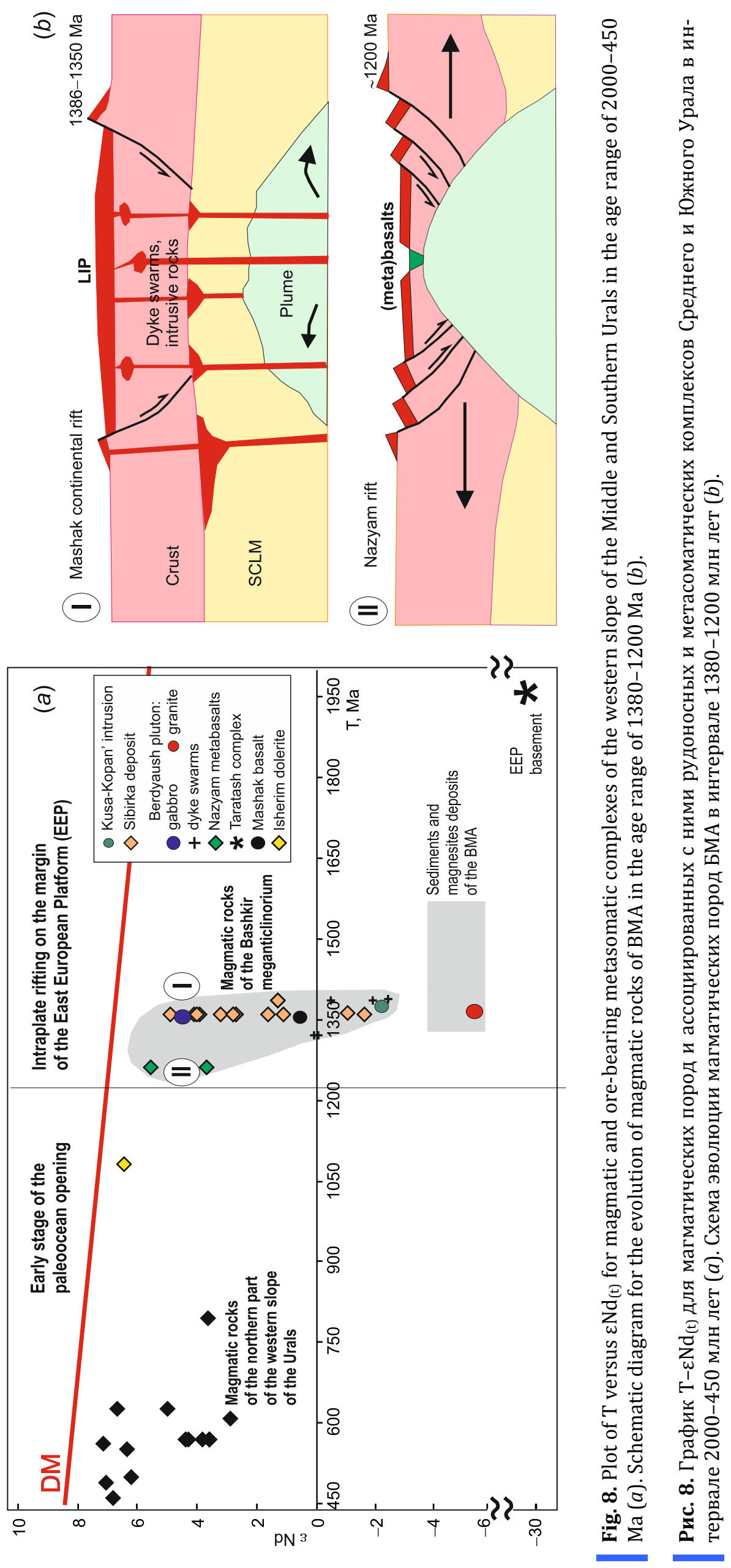


form a separate group in the Late Riphean-Vendian age cluster. Neoproterozoic magmatism manifested itself along the Uralian and Timanian margins of EEP. The Vendian datings are available for trachyriolites, granitoids and syenitoids [Petrov et al., 2005, Shardakova, 2016], basalts and trachybasalts (mainly high-titanium varieties), and alkaline picrites are widespread there. For example, in the Kvarkush-Kamennogorsk anticline, the Cadomian (Timanian) stage of tectogenesis is evidenced by the rocks of Dvoretsk, Kusy'a and Blagodatsky complexes. Their geochemical parameters also allow us to assume the plume genesis [Karpukhina et al., 2001; Petrov et al., 2005; Nosova et al., 2012; etc.].

The range of 1250-700 Ma was a prolonged and relatively amagmatic period in the development of the western continental margins of the Rifean-Vendian oceanic basin (see Fig. 8). There is a single dating in this time interval. This is the age of the metadolerite from the sill $(1079 \pm 41 \mathrm{Ma}$ [Petrov et al., 2014] intruded by quartzite sandstones of the Isherim Fm. (Late
Riphean). This metadolerite is considered to be derived from substantially depleted mantle $(\varepsilon N d+6.57)$.

Magmatic rocks of this age are unknown on the eastern slope of the Urals either. Probably, this gap corresponds to the stage of the most active opening of the Riphean-Vendian oceanic basin. Apparently, magmatism was mainly concentrated in the structures of the Middle Oceanic Ridge, and its traces hardly remained due to subsequent subduction of the oceanic crust.

The weak magmatic period in the EEP margin was completed by the Vendian-Cambrian magmatism of the Kvarkush-Kamennogorsk anticline (671-570 Ma [Petrov et al., 2005]). In BMA, there are intrusions of granites of the Barangulovo and Mazara massifs, and the Arsha basalts dated 725-705 Ma [Kuznetsov, 2009; Krasnobaev et al., 2015].

The isotope-geochemical $(\varepsilon N d-T)$ and metallogenic evolution of intrusive magmatism in the Uralian Mobile Belt in the age range of $1400-250 \mathrm{Ma}$ is schematically shown in Fig. 9. This scheme was compiled using the

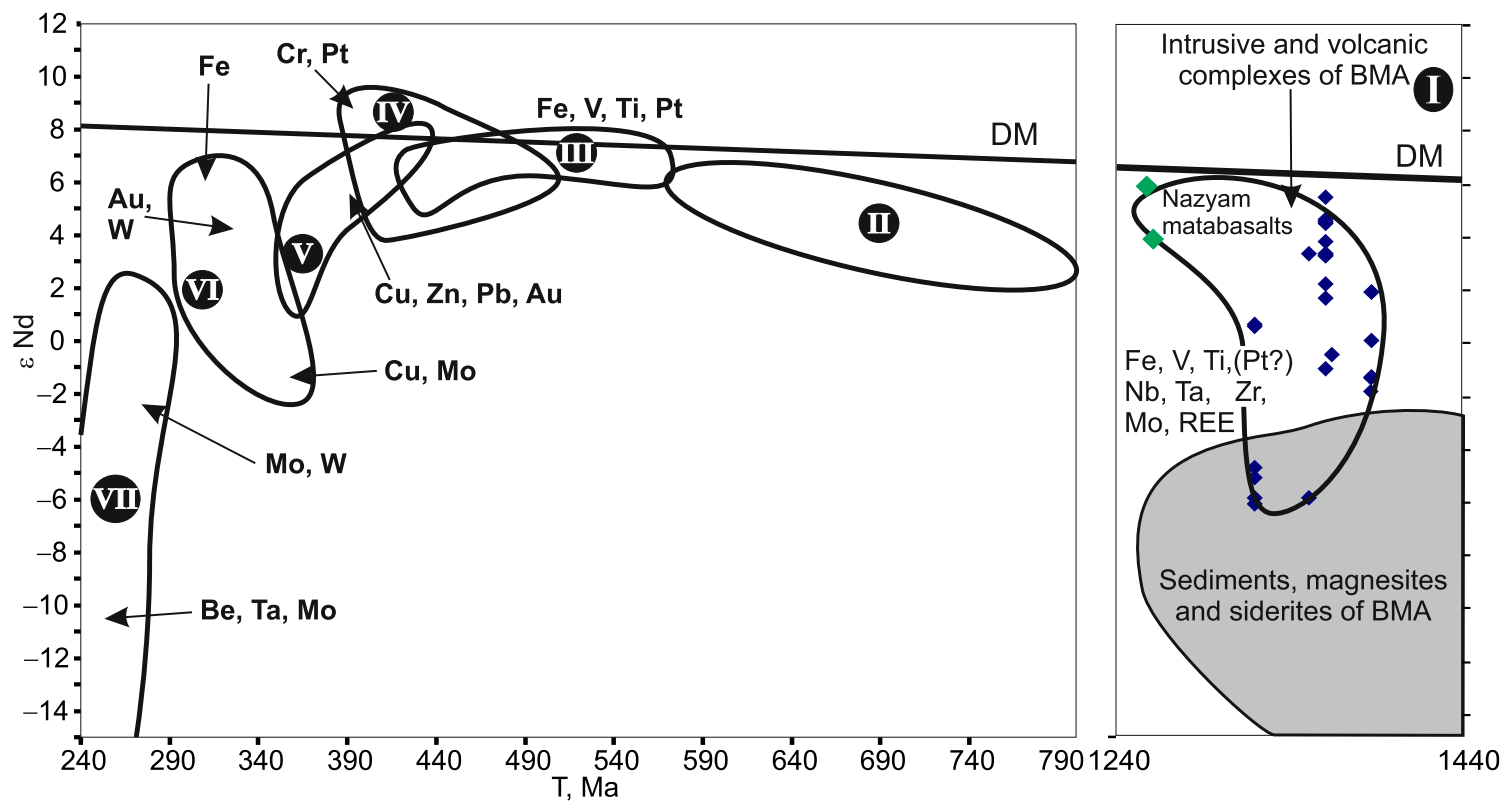

Fig. 9. The evolution of $\varepsilon N d$ isotope ratios during magmatic and ore-forming processes in the Middle and Southern Urals in the age interval of 1440-240 Ma.

I (right-hand side of this figure) - massifs, Ti-Fe-V and rare-earth metal deposits of BMA; II - lherzolite complexes of the Southern Urals (Nurali, Mindyak) and mafic rocks of the Kvarkush anticline; III - massifs and Fe-V-Ti-Pt deposits of the Uralian Platinum Belt; IV - ophiolitic massifs (Cr, Pt); V - island-arc associations ( $\mathrm{Cu}, \mathrm{Zn}, \mathrm{Au}, \mathrm{Pb})$; $\mathrm{VI}$ - continental-margin massifs and deposits $(\mathrm{Cu}-\mathrm{Mo}, \mathrm{Au}-\mathrm{W}, \mathrm{Fe}-\mathrm{Ti}-\mathrm{V}$ ), VII - late orogenic massifs and ore-bearing complexes (Mo-W, Be-Ta-Li, etc.). DM - depleted mantle evolution trend. Green diamonds show the positions of the Nyazam metabasalts.

Рис. 9. Изменение значений $\mathrm{Nd}$ в ходе эволюции магматических и рудообразующих процессов (Средний и Южный Урал) в интервале 1440-240 млн лет.

I (правая часть рисунка) - массивы, Ti-Fe-V и редкометалльные месторождения BMA; II - лерцолитовые комплексы Южного Урала (Нурали, Миндяк) и базиты Кваркушского антиклинория; III - массивы и Fe-V-Ti-Pt месторождения Уральского платиноносного пояса; IV - офиолитовые массивы (c Cr, Рt оруденением); V - островодужные ассоциации (Cu, Zn, Au, Pb); VI - oкраинноконтинентальные массивы и месторождения (Cu-Mo, $\mathrm{Au}-\mathrm{W}, \mathrm{Fe}-\mathrm{Ti}-\mathrm{V})$; VII - позднеорогенные и орогенные массивы и рудоносные комплексы (Mo-W, Be-Ta-Li и др.). DM - тренд деплетированной мантии. Зелеными ромбами показана позиция назямских метабазальтов. 
geochronological and isotopic data from more than 30 publications by Russian and foreign scientists, including [Karpukhina et al., 2001; Popov et al., 2002; Ronkin et al., 2003; Petrov et al., 2005; Nosova et al., 2009; Puchkov, 2013; Petrov et al., 2005; etc.].

At the Riphean stage of the geodynamic evolution of the western slope of the Urals, several successive stages of rifting destruction took place at the eastern margin of EEP.The lithospheric mantle derivatives were depleted (Fig. 9, right-hand side; field I). As a result, there is a gradual increase of the $\varepsilon \mathrm{Nd}$ values $(-2 \ldots+7)$, and a decrease in the primary ${ }^{87} \mathrm{Sr} /{ }^{86} \mathrm{Sr}$ ratio from 0.7060 to $0.7030-0.7025$. As seen from Fig. 9 (left-hand side), the depletion of lithospheric mantle derivatives continued until the Early Paleozoic (Fields II-IV, the grey arrow).

Paleozoic intrusive magmatism of the Urals in the range of $440-250 \mathrm{Ma}$ is mainly attributed to subduction and collision. This period is characterized by a different evolution pattern of isotope-geochemical parameters. The $\varepsilon N d$-values decrease from +8 to -14 , and increase in the ${ }^{87} \mathrm{Sr} /{ }^{86} \mathrm{Sr}$ primary ratio from 0.7025 to 0.710 and above. This evolution is characterized by discontinuous changes of island arc magmatism (440$360 \mathrm{Ma}$; field V), mantle-crustal magmatism of marginal-continental type (360-290 Ma; field VI), and the late collisional crustal and mantle-crustal granite magmatism (290-250 Ma; field VII).

The subsequent motion of the lithospheric plates and transformation of the continental margins resulted in a change of the isotopic-geochemical parameters of the igneous rocks and related ores [Khanchuk et al., 2016]. These settings in the Southern Urals caused formation of such specific magmatic complexes as, for example, the Early Carboniferous Magnitogorsk gabbro-granite and the Early Permian Stepninsk monzodiorite-granite series. Their associated skarn-magnitite ores of the Magnitogorsk and Kachar deposits have higher $\varepsilon N d$ values $(+5 \ldots+6$, field VI). This trend is shown by the Fe arrow in Fig. 9.

Regular changes in the isotopic and geochemical parameters during the closure of the Uralian paleocean and the formation of the continental crust of the Uralian orogen were accompanied by synchronous changes in the composition of endogenous mineralization as follows: $\mathrm{Cu}$-pyrite, $\mathrm{Au}-\mathrm{Cu}$-porphyry and $\mathrm{Cu}$-Mo porphyry mineralization (island-arc stage) $\rightarrow$ skarn magnetite and $\mathrm{Au}$-sulfide-quartz (with scheelite) mineralization (continental-margin and transform-collision stages $\rightarrow$ Mo-W and rare-metal mineralization (Be, Ta, Mo, $\mathrm{Li}$, etc.) resulted from the late collisional mantle-crustal and crustal granite magmatism.

The general trend of the isotopic-geochemical evolution of magmatism at different time intervals can indicate the inheritance of the processes of oceanic generation in the Riphean-Vendian and the subsequent Paleozoic stage of evolution in the study area.

\section{CONCLUSIONS}

In the Lower-Middle Riphean, the eastern margin of EEP (i.e. the western paleocontinental sector of the Urals) underwent several successive stages of intraplate rifting. The riftogenic activity reached its maximum in the Middle Riphean, when the LIP was formed.Its genesis may be related to the mantle plume. The latter initiated the process of opening of the Nazyam rift (1250-1150 Ma) followed by the complete break-up of the continental crust.

During the Middle Riphean, the igneous rocks of BMA varied from E-MORB and OIB to the rocks similar to $\mathrm{N}-\mathrm{MORB}$. The $\varepsilon \mathrm{Nd}$ values vary from negative $(-6)$ for the derivatives of the mature continental crust to positive $(+4 \ldots+5$ and above) for the Nazyam metabasalts, and thus give evidence of the lithosphere mantle depletion with time. Apparently, the relatively amagmatic period (1250-700 Ma) indicates that the period of opening and existence of the Riphean-Vendian ocean was prolonged. Acording to the data on the Northern and Polar Urals rocks, the closure of an oceanic basin (Protouralian or Timanian ocean) took place at the Late Vendian - Early Cambrian [Puchkov, 2010; Kuznetsov et al., 2014]. Later on, the Uralian paleoocean was opened, and its evolution lasted from the Ordovician to the Permian and completed due to collision processes.

\section{ACKNOWLEDGMENTS}

The work was carried out within the framework of theme no. 0393-2016-0020 of the State Task for IGG UB RAS.

\section{REFERENCES}

Barrat J.-A., Fourcade S., Jahn B.-M., Cheminee J.-L., Capdevila R., 1998. Isotope (Sr, Nd, Pb, O) and trace-element geochemistry of volcanics from the Erta-Ale Range (Ethiopia). Journal of Volcanology and Geothermal Research 80 (1-2), 85-100. https://doi.org/10.1016/S0377-0273(97)00016-4.

Daoud M.A., Maury R.C., Barrat J.-A., Taylor R.N., Le Gall B., Guillou H., Cotton J., Rolet J., 2010. A LREE-depleted component in the Afar plume: further evidence from Quaternary Djibouti Basalts. Lithos 114 (3), 327-336. https:// doi.org/10.1016/j.lithos.2009.09.008. 
Deniel C., Vidal P., Coulon C., Vellutini P.J., Piguet P., 1994. Temporal evolution of mantle sources through continental rifting: the volcanism of Djibouti (Afar). Journal of Geophysical Research: Solid Earth 99 (B2), 2853-2869. https:// doi.org/10.1029/93JB02576.

DePaolo D.J., 1981. Neodymium isotope geochemistry. Springer, Berlin, Heidelberg, New York, 187 p.

Duffield W.A., Bullen T.D., Clynne M.A., Fournier R.O., Janik C.J., Lanphere M.A., Lowenstern J.B., Smith J.G., Woldegiorgis L., Kahsai G., Weldemariam K., Tesfai T., 1997. Geothermal Potential of the Alid Volcanic Center, Danakil Depression, Eritrea. USGS Open-File Report 97-291,62 p.

Ernst R.E., 2014. Large Igneous Provinces. Cambridge University Press, Cambridge, 585 p.

Ernst R.E., Pease V., Puchkov V.N., Kozlov V.I., Sergeeva N.D., Hamilton M., 2006. Geochemical characterization of Precambrian magmatic suites of the Southeastern margin of the East European Craton, Southern Urals, Russia. In: Geologicheskii Sbornik, vol. 5. IG BSC RAS, Ufa, p. 119-161.

Fershtater G.B., 2015. The main features of the Uralian Paleozoic magmatism and the epioceanic nature of the orogen. Mineralogy and Petrology 107 (1), 39-52. https://doi.org/10.1007/s00710-012-0218-6.

Fershtater G.B., Kholodnov V.V., Borodina N.S., 2001. Conditions of formation and origin of Riphean ilmenite-titanomagnetite deposits in the Urals. Russian Geology of Ore Deposits 43 (2), 101-116.

Fershtater G.B., Kholodnov V.V., Pribavkin S.V., Borodina N.S., Bocharnikova T.D., Gottman I.A., 2005. Riftogenic magmatism and iron ore deposition in the South Urals. Geology of Ore Deposits 47 (5), 382-402.

Field L., Blundy J.D., Brooker R.A., Wright T.L., Yirgu G., 2012. Magma storage conditions beneath Dabbahu volcano (Ethiopia): constrained by petrology, seismicity and satellite geodesy. Bulletin of Volcanology 74 (5), 981-1004. https://doi.org/10.1007/s00445-012-0580-6.

Garan M.I., Poyarkova N.V., Zybarieva V.G., Zorin S.A., Frolova T.I., 1964. Tectonic Map of the Urals. Scale 1:200000 (N-40-XII). Uralgeologiya, Sverdlovsk (in Russian) [Гарань М.И., Пояркова Н.В., Зубарева В.Г., Зорин С.А., Фролова Т.И., 1964. Тектоническая карта Урала. Масштаб 1:200000 (N-40-XII). Свердловск: Уралгеология].

Gorozhanin V.M., 1998. The primary isotopic content of Sr in magmatic complexes of the South Urals. In: Magmatism and geodynamics. IGG UB RAS, Yekaterinburg, p. 98-108 (in Russian) [Горожанин В.М. Первичные отношения изотопов Sr в магматических комплексах Южного Урала // Магматизм и геодинамика. Екатеринбург: УрО PAH, 1998. C. 98-108].

Grazhdankin D.V., Marusin V.V., Meert J., Krupenin M.T., Maslov A.V., 2011. Kotlin regional stage in the South Urals. Doklady Earth Sciences 440 (1), 1222-1226. https://doi.org/10.1134/S1028334X11090170.

Ivanov K.S., Kontorovich V.A., Puchkov V.N., Fedorov Yu.N., Erokhin Yu.V., 2014. Tectonics of the Urals and the basement of the West Siberian: main features of the geological structure and evolution. Geology and Mineral Resources of Siberia (2s), 22-35 (in Russian) [Иванов К.С., Конторович В.А., Пучков В.Н., Федоров Ю.Н., Ерохин Ю.В. Тектоника Урала и фундамента Западной Сибири: основные черты геологического строения и развития // Геология и минерально-сырьевые ресурсы Сибири. 2014. № 2c. С. 22-35].

Karpukhina E.V., Pervov V.A., Zhuravlev D.Z., 2001. Petrology of the subalkaline volcanism in the Western slope of the Ural Mountains - an Indicator of the Late Vendian Rifting. Petrology 9 (5), 415-436.

Karsten L.A., Ivanov K.S., Maslov A.V., Bankvitz P., Dulski P., 1997. The nature of mashak volcano-sedimentary suite of the Bashkirian anticline: new geochemical data. In: The Riphean of the Northern Eurasia: geology, general problems of stratigraphy. Ural Branch of RAS, Ekaterinburg, p. 155-165 (in Russian) [Карстен Л.А., Иванов К.С., Маслов А.В., Банквиц П., Дульски П. Природа машакской вулканогенно-осадочной ассоциации Башкирского антиклинория: новые геохимические данные // Рифей Северной Евразии. Геология. Общие проблемы стратиграфии. Екатеринбург: УрО РАН, 1997. С. 155-165].

Khanchuk A.I., Kemkin I.V., Kruk N.N., 2016. The Sikhote-Alin orogenic belt, Russian South East: terranes and the formation of continental lithosphere based on geological and isotopic data. Journal of Asian Earth Science 120, 117-138. https://doi.org/10.1016/j.jseaes.2015.10.023.

Kholodnov V.V., Fershtater G.B., Borodina N.S., Shardakova G.Yu., Pribavkin S.V., Shagalov E.S., Bocharnikova T.D., 2006. Granite magmatism of junction zone between the Urals and East European platform (Southern Urals). Litosfera (Lithosphere) (3), 3-27 (in Russian) [Холоднов В. В, Ферштатер Г.Б., Бородина Н.С., Шардакова Г.Ю., Прибавкин С.В., Шагалов Е.С., Бочарникова Т.Д. Гранитоидный магматизм зоны сочленения Урала и Восточно-Европейской платформы (Южный Урал) // Литосфера. 2006. № 3. С. 3-27].

Kholodnov V.V., Fershtater G.B., Ronkin Yu.L., Borodina N.S., Pribavkin S.V., Lepikhina O.P., 2010. Sm-Nd and Rb-Sr ages of gabbroids, granitoids, and titanomagnetite ores from layered intrusions of the Kusa-Kopan Complex (South Urals). Doklady Earth Sciences 432 (2), 732-736. https://doi.org/10.1134/S1028334X10060048.

Kholodnov V.V., Shagalov E.S., 2012. The Late and Lower age boundaries of the Middle Riphean (Ti-Fe-V) intrusions of the kusinsko-kopanskii complex in the South Urals: U-Pb dating of zircons from the Medvedevskoe deposit. Doklady Earth Sciences 446 (2), 1171-1175. https://doi.org/10.1134/S1028334X12080211.

Krasnobaev A.A., Busharina S.V., Puchkov V.N., Kozlov V.I., Sergeeva N.D., Lepekhina E.N., 2013. Zirconology of Navysh volcanic rocks of the Ai Suite and the problem of the age of the Lower Riphean boundary in the Southern Urals. Doklady Earth Sciences 448 (2), 185-190. https://doi.org/10.1134/S1028334X13020050.

Krasnobaev A.A., Kozlov V.I., Puchkov V.N., Rodionov N.V., Nekhorosheva A.G., Kiseeva K.N., 2008. The Akhmerovo granite massif: a proxy of mesoproterozoic intrusive magmatism in the Southern Urals. Doklady Earth Sciences 418 (1), 103-108. https://doi.org/10.1134/S1028334X08010236. 
Krasnobaev A.A., Kozlov V.I., Puchkov V.N., Sergeeva N.D., Busharina S.V., 2012. New data about Arshinian volcanites zircon geochronology. Litosfera (Lithosphere) (4), 127-139 (in Russian) [Краснобаев А.А., Козлов В.И., Пучков В.Н., Сергеева Н.Д., Бушарина С.В. Новые данные по цирконовой геохронологии аршинских вулканитов (Южный Урал) // Литосфера. 2012. № 4. С. 127-139].

Krasnobaev A.A., Popov V.S., Belyatskii B.V., 2011. Zirconology of nepheline syenite of the Berdyaush Massif (Southern Urals). Doklady Earth Sciences 436 (1), 134-137. https://doi.org/10.1134/S1028334X11010260.

Krasnobaev A.A., Puchkov V.N., Sergeeva N.D., Busharina S.V., 2015. Uranium-lead age of zircons from granites and the substrate of the Mazara massif (Southern Urals). Doklady Earth Sciences 463 (1), 719-725. https://doi.org/ 10.1134/S1028334X15070119.

Krupenin M.T., 2004. The Middle Riphean time on the western slope of the Southern Urals: mineragenic and geodynamic implications. Doklady Earth Sciences 399 (9), 1189-1191.

Krupenin M.T., Kuznetsov A.B., Konstantinova G.V., 2016. Sr-Nd Systematics and REE distribution in the type magnesite deposits in Lower Riphean of South Urals province. Litosfera (Lithosphere) (5), 58-80 (in Russian) [Крупенин М.T., Кузнецов А.Д., Константинова Г.В. Sr-Nd систематика и распределение РЗЭ в типовых магнезитовых месторождениях нижнего рифея Южно-Уральской провинции // Литосфера. 2016. № 5. С. 58-80].

Kuznetsov N.B., 2009. Protouralides-Tymanide Complexes and the Late Precambrian - Early Paleozoic Evolution of the Eastern and Northeastern Frame of the East European Platforms. Brief PhD Thesis (Doctor of Geology and Mineralogy). IPE RAS, Moscow, 51 p. (in Russian) [Кузнецов Н.Б. Комплексы протоуралид-тиманид и позднедокембрийско-раннепалеозойская эволюция восточного и северо-восточного обрамления Восточно-Европейской платформы: Автореф. дис. ... докт. геол.-мин. наук. М.: ИФЗ РАН, 2009. 51 с.].

Kuznetsov N.B., Belousova E.A., Alekseev A.S., Romanyuk T.V., 2014. New data on detrital zircons from the sandstones of the lower Cambrian Brusov Formation (White Sea region, East-European Craton): Unravelling the timing of the onset of the Arctida-Baltica collision. International Geology Review 56 (16), 1945-1963. https://doi.org/10.1080/ 00206814.2014 .977968$.

Kuznetsov N.B., Belousova E.A., Romanyuk T.V., Degtyarev K.E., Maslov A.V., Gorozhanin V.M., Gorozhanina E.N., Pyzhova E.S., 2017. First results of $\mathrm{U} / \mathrm{Pb}$ dating of detrital zircons from middle Riphean sandstones of the Zigalga Formation, South Urals. Doklady Earth Sciences 475 (2), 863-867. https://doi.org/10.1134/S1028334X17080244.

Kuznetsov N.B., Soboleva A.A., Udoratina O.V., Hertseva M.A., Andreichev V.L., 2007. Pre-Ordovician tectonic evolution and volcano-plutonic associations of the Timanides and northern Pre-Uralides, northeast part of the East European Craton. Gondwana Research 12 (3), 305-323. https://doi.org/10.1016/j.gr.2006.10.021.

Larin A.M., 2011. Rapakivi Granites and Associated Rocks. Nauka, St. Petersburg, 420 p. (in Russian) [Ларин А.М. Граниты рапакиви и ассоциирующие породы. СПб.: Наука, 2011. 402 с.].

Levashova N.M., Bazhenov M.L., Meert J.G., Kuznetsov N.B., Golovanova I.V., Danukalov K.N., Fedorova N.M., 2013. Paleogeography of Baltica in the Ediacaran: paleomagnetic and geochronological data from the clastic Zigan Formation, South Urals. Precambrian Research 236, 16-30. https://doi.org/10.1016/j.precamres.2013.06.006.

Lowenstern J.B., Charlier B.L.A., Clynne M.A., Wooden J.L., 2006. Extreme U-Th disequilibrium in rift-related basalts, rhyolites and granophyric granite and the timescale of rhyolite generation, intrusion and crystallization at Alid volcanic center, Eritrea. Journal of Petrology 47 (11), 2105-2122. https://doi.org/10.1093/petrology/egl038.

Ludwig K.R., 2001. Isoplot/Ex ver. 2.49. Berkeley Geochronology Center Special Publication 1a. 111 p.

Maslov A.V., 2004. Riphean and Vendian sedimentary sequences of the Timanides and Uralides, the eastern periphery of the East European Craton. In: D.G. Gee, V. Pease (Eds.), The Neoproterozoic timanide orogen of Eastern Baltica Geological Society, London, Memories, vol. 30, p. 19-35. https://doi.org/10.1144/GSL.MEM.2004.030.01.03.

Maslov A.V., Erdtmann B.D., Ivanov K.S., Krupenin M.T., 1997. The main tectonic events, depositional history and the palaeogeography of the Southern Urals during the Riphean - Early Palaeozoic. Tectonophysics 276 (1-4), 313-335. https://doi.org/10.1016/S0040-1951(97)00064-4.

Maslov A.V., Ronkin Y.L., Podkovyrov V.N., Gareev E.Z., 2014. Contribution of Grenvillian events to the formation of most complete Riphean sedimentary successions in Northern Eurasia. Stratigraphy and Geological Correlation 22 (2), 160-174. https://doi.org/10.1134/S0869593814020063.

Nosova A.A., Gorozhanin V.M., Larionova Yu.O., Dubinina E.O., 2009. Sm-Nd, Rb-Sr, O features of the Late Pre-Cambrian dolerites and picrites of the West Urals: the example of two contrast isotopic-geochemical types of intraplate magmatism. In: Isotopic systems and the time of geological processes. St. Petersburg, p. 63-65 (in Russian) [Hocoва А.А., Горожанин В.М., Ларионова Ю.О., Дубинина Е.О. Изотопные (Sm-Nd, Rb-Sr, O) особенности позднедокембрийских долеритов и пикритов Западного Урала: пример двух контрастных изотопно-геохимических типов внутриплитного магматизма // Изотопные системы и время геологических процессов. СПб., 2009. T. 2. C. $63-65]$.

Nosova A.A., Kargin A.V., Larionova Yu.O., Sazonova L.V., Gorozhanin V.M., Kovalev S.G., 2012. Mesoproterozoic withinplate province of the Western Urals: main petrogenetic rock types and their origin. Petrology 20 (4), 356-390. https://doi.org/10.1134/S086959111204008X.

Ovchinnikova G.V., Kuznetsov A.B., Krupenin M.T., Gorokhov I.M., Kaurova O.K., Maslov A.V., Gorokhovskii B.M., 2014. U-Pb systematics of Proterozoic magnesites of the Satka deposit (South Urals): the source of the fluid and age. Doklady Earth Sciences 456 (1), 590-593. https://doi.org/10.1134/S1028334X14050286. 
Parnachev V.P., 1981. Volcanic complexes and tectonic setting of the western slope of the South Urals in the Late PreCambrian In: V.P. Parnachev, V.G. Korinevsky (Eds.), Ancient volcanism of the Southern Urals. Ural Scientific Center of USSR Acad. Sci., Sverdlovsk, p. 18-30 (in Russian) [Парначев В.П. Вулканические комплексы и тектонический режим западного склона Южного Урала в позднем докембрии // Древний вулканизм Южного Урала / Ред. В.П. Парначев, В.Г. Кориневский. Свердловск: УНЦ АН СССР, 1981. С. 18-30].

Pearce J.A., 2008. Geochemical fingerprinting of oceanic basalts with applications to ophiolite classification and the search for Archean oceanic crust. Lithos 100 (1), 14-48. https://doi.org/10.1016/j.lithos.2007.06.016.

Petrov G.A., Maslov A.V., Ronkin Yu.L., 2005. Pre-Paleozoic magmatic complexes of the Kvarkush-Kamennogorsk anticline (Middle Urals): new data about geochemistry and geodynamic settings. Litosfera (Lithosphere) (4), 42-69 (in Russian) [Петров Г.А., Маслов А.В., Ронкин Ю.Л. Допалеозойские магматические комплексы КваркушскоКаменногорского антиклинория (Средний Урал): новые данные по геохимии и геодинамике // Литосфеpa. 2005. № 4. C. 42-69].

Petrov G.A., Ronkin Yu.L., Maslov A.V., Tristan N.I., Gerdes A., 2014. New data on composition and age of granites from the Isherim anticlinorium and boundary of the Timanides in the North Urals. Doklady Earth Sciences 459 (2), 1514-1518. https://doi.org/10.1134/S1028334X14120290.

Popov V.S., Bogatov V.I., Zhuravlev D.Z., 2002. Sources of granitic magma and the Earth's crust formation in the Central and Southern Urals: Sm-Nd and Rb-Sr isotopic evidence. Petrology 10 (4), 343-361.

Puchkov V.N., 2000. Paleogeodynamics of the Middle and Southern Urals. Dauria, Ufa, 146 p. (in Russian) [Пучков В.Н. Палеогеодинамика Южного и Среднего Урала. Уфа: Даурия, 2000. 146 с.].

Puchkov V.N., 2010. Geology of the Urals and Cis-Urals. DesignPoligraphService, Ufa, 280 p. (in Russian) [Пучков В.Н. Геология Урала и Приуралья. Уфа: ДизайнПолиграфСервис, 2010. 280 с.].

Puchkov V.N., 2012. Dike swarms and related igneous complexes in the Urals. Geotectonics 46 (1), 37-46. https:// doi.org/10.1134/S0016852112010050.

Puchkov V.N., 2013. Structural stages and evolution of the Urals. Mineralogy and Petrology 107 (1), 3-37. https:// doi.org/10.1007/s00710-012-0263-1.

Puchkov V.N., 2016. Relationship between plume and plate tectonics. Geotectonics 50 (4), 425-438. https://doi.org/ 10.1134/S0016852116040075.

Puchkov V.N., Bogdanova S.V., Ernst R.E., Kozlov V.I., Krasnobaev A.A., Söderlund U., Wingate M.T.D., 2013. The ca. 1380 Ma Mashak igneous event of the Southern Urals. Lithos 174, 109-124. https://doi.org/10.1016/j.lithos.2012. 08.021.

Rogers N.W., 1993. The isotope and trace element geochemistry of basalts from the volcanic islands of the southern Red Sea. In: H.M. Prichard, T. Alabaster, N.B.W. Harris, C.R. Neary (Eds.), Magmatic processes and plate tectonics. Geological Society, London, Special Publications, vol. 76, p. 455-467. https://doi.org/10.1144/GSL.SP.1993.076. 01.24 .

Ronkin Yu.L., Ivanov K.S., Shmelev V.R., Lepikhina O.P., 2003. Sm-Nd isotopic data of the gabbro-norite of Kumba massif: Platinum-bearing belt of the Urals. In: Proceedings of II All-Russia Conference on Geochronology. St. Petersburg state university, St. Petersburg, p. 424-427 (in Russian] [Ронкин Ю.Л., Иванов К.С., Шмелев В.Р., Лепихина О.П. Sm-Nd изотопное датирование габбро-норита Кумбинского массива: Платиноносный пояс Урала // Материалы II Российской конференции по геохронологии. СПб.: СПбГУ, 2003. С. 424-427].

Ronkin Yu.L., Maslov A.V., Matukov D.I., Lepikhina O.P., Popova O.V., Lepikhina G.A., 2006. The Berdyaush massif: 1350 \pm 10 Ma or older? In: Yearbook-2005. Yekaterinburg, p. 310-315 (in Russian) [Ронкин Ю.Л., Маслов А.В., Матуков Д.И., Лепихина О.П., Попова О.Ю., Лепихина Г.А. Бердяушский массив: $1350 \pm 10$ млн лет или древнее? // Ежегодник-2005. Екатеринбург, 2006, С. 310-314].

Ronkin Yu.L., Maslov A.V., Tichomirova M.V., 2016. The Southern Urals Large Igneous Province with an age of approximately 1380 Ma: precision U-Pb ID-TIMS constraints. Doklady Earth Sciences 468 (2), 587-592. https://doi.org/ 10.1134/S1028334X16060210.

Ronkin Yu.L., Sindern S., Maslov A.V., Matukov D.I., Kramm U., Lepikhina O.P., 2007. Oldest (3.5 Ga) zircons of the Urals: U-Pb (SHRIMP-II) and TDM constraints. Doklady Earth Sciences 415 (2), 860-865. https://doi.org/10.1134/S10 $28334 \mathrm{X} 07060074$.

Rooney T.O., Mohr P.A., Dosso L., Hall C.M., 2013. Geochemical evidence of mantle reservoir evolution during progressive rifting along the western Afar margin. Geochimica et Cosmochimica Acta 102, 65-88. https://doi.org/10.1016/ j.gca.2012.08.019.

Samygin S.G., Belova A.A., Ryazantsev A.V., Fedotova A.A., 2010. Fragments of the Vendian convergent borderland in the South Urals. Doklady Earth Sciences 432 (2), 726-731. https://doi.org/10.1134/S1028334X10060036.

Sazonova L.V., Nosova A.A., Larionova Yu.O., 2011. Mesoproterozoic picrites of the eastern frame of the East European Platform: petrogenesis and peculiarities of the composition of olivine and clinopyroxene. Litosfera (Lithosphere) (3), 64-83 (in Russian) [Сазонова Л.В., Носова А.А., Ларионова Ю.О. Мезопротерозойские пикриты восточной окраины Восточно-Европейской платформы: петрогенезис и особенности составов оливина и клинопироксена // Литосфера. 2011. № 3. С. 64-83].

Shagalov E.S., Kholodnov V.V., Nosova A.A., Soloshenko N.G., Streletskaya M.V., Kiseleva D.V., Gorozhankin V.M., 2014. About the age of host rocks in the Sibirka rare metal deposit. In: 2013 Yearbook of IGG UB RAS, Issue 161. IGG UB RAS, Yekaterinburg, p. 362-366 (in Russian] [Шагалов Е.С., Холоднов В.В., Носова А.А., Солошенко Н.Г., Стре- 
лецкая М.В., Киселева Д.В., Горожанин В.М. К вопросу о возрасте вмещающих пород редкометалльного месторождения Сибирка: Sm-Nd- и U-Pb (циркон) изотопные данные // Ежегодник-2013. Труды ИГГ УрО РАН, вып. 161. Екатеринбург: ИГГ УрО РАН, 2014. С. 362-366].

Shardakova G.Yu., 2016. Geochemistry and isotopic ages of granitoids of the Bashkirian anticlinorium: evidence for several pulses of tectono-magmatic activity at the junction zone between the Uralian orogen and East European Platform. Geochemistry International 54 (7), 594-608. https://doi.org/10.1134/S0016702916070089.

Sindern S., Hetzel R., Schulte B.A., Kramm U., Ronkin Yu.L., Maslov A.V., Lepikhina O.P., 2005. Proterozoic magmatic and tectonometamorphic evolution of the Taratash complex, Central Urals, Russia. International Journal of Earth Sciences 94 (3), 319-335. https://doi.org/10.1007/s00531-005-0489-9.

Sobolev I.D. (Ed.), 1977. Tectonic Map of the Urals. Scale 1:1000000. Explanatory Note. Nauka, Moscow, 120 p. (in Russian) [Тектоника Урала. Объяснительная записка к тектонической карте Урала масштаба 1:1000000 / Ред. И.Д. Соболева. М.: Наука, 1977. 120 с.].

Soboleva A.A., Karchevsky A.F., Efanova L.I., Kuznetsov N.B., Grove M., Sobolev I.D., Marin M.V., 2012. Evidence for Late Riphean granite formation in the Polar Urals. Doklady Earth Sciences 442 (2), 181-187. https://doi.org/10.1134/ S1028334X12020080.

Stratotype of the Riphean. Stratigraphy. Geochronology, 1983. Geological Institute of USSR Acad. Sci., Moscow, 184 p. (in Russian) [Стратотип рифея. Стратиграфия. Геохронология. М.: ГИН АН СССР, 1983. 184 с.].

Sun S.S., 1982. Chemical composition and origin of the Earth's primitive mantle. Geochimica et Cosmochimica Acta 46, 179-192.

Teklay M., Scherer E.E., Mezger K., Danyushevsky L., 2010. Geochemical characteristics and Sr-Nd-Hf isotope compositions of mantle xenoliths and host basalts from Assab, Eritrea: implications for the composition and thermal structure of the lithosphere beneath the Afar depression. Contribution to Mineralogy and Petrololy 159 (5), 731-751. https://doi.org/10.1007/s00410-009-0451-0.

Tevelev Al.V., Kosheleva I.A., Khotylev A.O., Tevelev Ark.V., Prudnikov I.A., 2014. Peculiarities of the structure and evolution of the Riphean Ai volcanic complex, South Urals. Moscow University Geology Bulletin 69 (5), 289-298. https:// doi.org/10.3103/S0145875214050111.

Tevelev Al.V., Kosheleva I.A., Tevelev Ark.V., Khotylev A.O., Moseichuk V.M., Petrov V.I., 2014a. New data on the isotope ages of the Taratash and Aleksandrovka metamorphic complexes. Moscow University Geology Bulletin 70 (1), 24-40. https://doi.org/10.3103/S0145875215010081.

Tevelev Al.V., Mosejchuk V.M., Tevelev Ark.V., Shkursky B.B., 2017. The zircon-age distribution in metamorphic rocks of the Taratash block, Southern Urals (an initial provenance signal). Moscow University Geology Bulletin 72 (5), 314-319. https://doi.org/10.3103/S0145875217050106.

Volker F., Altherr R., Jochum K.P., McCulloch M.T., 1997. Quaternary volcanic activity of the southern Red Sea: new data and assessment of models on magma sources and Afar plume-lithosphere interaction. Tectonophysics 278 (1-4), 15-29. https://doi.org/10.1016/S0040-1951(97)00092-9.

Zoloev K.K., Levin V.Ya., Mormil S.I., Shardakova G.Yu., 2004. Mineragenesis and Deposits of Rare Metals, Mo, and W in the Urals. Ural Branch of RAS, Yekaterinburg, 336 p. (in Russian) [Золоев К.К., Левин В.Я., Мормиль С.И., Шардакова Г.Ю., 2004. Минерагения и месторождения редких металлов, молибдена, вольфрама Урала. Екатеринбург: УрО РАН, 2004. 336 с.].

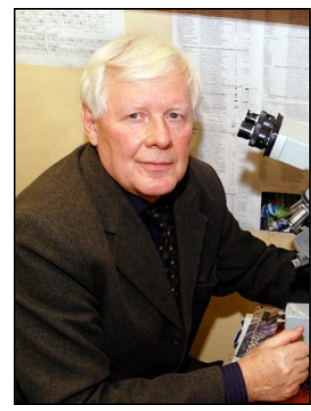

Vladimir V. Kholodnov, Doctor of Geology and Mineralogy, Professor, Head of Laboratory A.N. Zavaritsky Institute of Geology and Geochemistry, Ural Branch of RAS 15 Akademik Vonsovsky street, Yekaterinburg 620016, Russia e-mail: holodnov@igg.uran.ru

Владимир Васильевич Холоднов, докт. геол.-мин. наук, профессор, зав. лабораторией Институт геологии и геохимии им. академика А.Н. Заварицкого УрО РАН 620016, Екатеринбург, ул. Академика Вонсовского, 15, Россия e-mail: holodnov@igg.uran.ru 


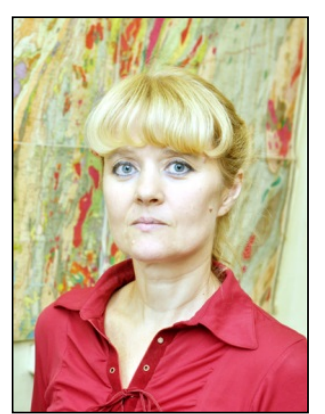

Galina Yu. Shardakova, Candidate of Geology and Mineralogy, Lead Researcher A.N. Zavaritsky Institute of Geology and Geochemistry, Ural Branch of RAS

15 Akademik Vonsovsky street, Yekaterinburg 620016, Russia

Ural State Mining University

30 Kuibysheva street, Yekaterinburg 620144, Russia

\e-mail: shardakova@igg.uran.ru; shardakovagalina@mail.ru

Галина Юрьевна Шардакова, канд. геол.-мин. наук, в.н.с.

Институт геологии и геохимии им. академика А.Н. Заварицкого УрО РАН

620016, Екатеринбург, ул. Академика Вонсовского, 15, Россия

Уральский государственный горный университет

620144, Екатеринбург, ул. Куйбышева, 30, Россия

\e-mail: shardakova@igg.uran.ru; shardakovagalina@mail.ru

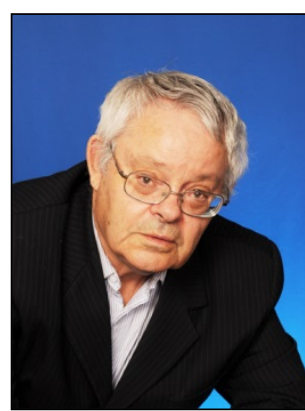

German B. Fershtater, Doctor of Geology and Mineralogy, Professor, Chief Researcher A.N. Zavaritsky Institute of Geology and Geochemistry, Ural Branch of RAS 15 Akademik Vonsovsky street, Yekaterinburg 620016, Russia e-mail: fershtater@igg.uran.ru

Герман Борисович Ферштатер, докт. геол.-мин. наук, профессор, г.н.с. Институт геологии и геохимии им. академика А.Н. Заварицкого УрО РАН 620016, Екатеринбург, ул. Академика Вонсовского, 15, Россия e-mail: fershtater@igg.uran.ru

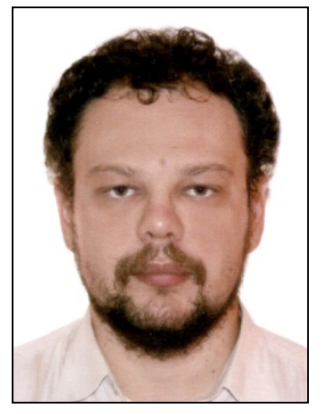

Eugeny S. Shagalov, Candidate of Geology and Mineralogy, Senior Researcher A.N. Zavaritsky Institute of Geology and Geochemistry, Ural Branch of RAS

15 Akademik Vonsovsky street, Yekaterinburg 620016, Russia Ural State Mining University

30 Kuibysheva street, Yekaterinburg 620144, Russia e-mail: shagalov@igg.uran.ru

Евгений Сергеевич Шагалов, канд. геол.-мин. наук, с.н.с.

Институт геологии и геохимии им. академика А.Н. Заварицкого УрО РАН

620016, Екатеринбург, ул. Академика Вонсовского, 15, Россия

Уральский государственный горный университет

620144, Екатеринбург, ул. Куйбышева, 30, Россия

e-mail: shagalov@igg.uran.ru 